\title{
EESTI KEELE KASUTUSVARIANDID: KORPUSTEST TULENEV KÄÄNDEVORMIDE VÕRDLEV ANALÜÜS
}

\author{
Pille Eslon, Erika Matsak
}

\begin{abstract}
Ülevaade. Eesti keele keeletehnoloogilise ressursi olemasolu annab võimaluse korpusest tulenevalt võrrelda kahte eesti keele aktiivselt kasutatavat varianti - kirjakeelt ja õppijakeelt. Tegemist on autentse keeleainesega, mille uurimisel saab rakendada tarkvara ning erinevaid kvantitatiivse ja kvalitatiivse analüüsi meetodeid, sh sõnavormide ja nende kasutuskontekstide sageduse automaatset leidmist. Saadud tulemustest peaks ilmnema, missugused vormid on erinevates keelevariantides sagedased; missuguseid tüüpilisi, ebatüüpiliselt või spetsiifilist laadi kollokatsioonilisi üksuseid korpustes esineb; missugused grammatilised konstruktsioonid on erinevatele keelevariantidele tegelikult iseloomulikud ja tavapärased; missugust osa sõnavarast, vormidest ja konstruktsioonidest erinevad keelekasutajad tegelikult eelistavad.*
\end{abstract}

Võtmesõnad: korpuslingvistika, korpustest tulenev võrdlev analüüs, käändegrammatika, käändevormide kasutuseelistused eesti keeles, eesti keel

\section{Eesmärk}

Uurimuse eesmärk on võrrelda käändekasutust kahes eesti keele variandis - kirjakeeles ja õppijakeeles. Aluseks on võetud Eesti Keele Instituudi (EKI) tekstikorpus ${ }^{1}$ ja Tallinna Ülikooli eesti vahekeele korpus (EVKK $)^{2}$. Nende ressursside põhjal tuuakse välja eesti keele nelja sagedasema nimisõna käändevormide sagedus ning kirjeldatakse nende sõnade morfoloogilist paradigmat. Statistikast peaks selguma, mil määral on sõna semantika seotud grammatiliste vormide moodustamise ning esinemissagedusega korpuses. Samas ei anna see teave tegelikult midagi olulist vormieelistuste kohta tekstiloomes. Küsimus aga on selles, missuguseid konstruktsioone ja käändevorme tekstiloomes eelistatakse ning miks. Seetõttu otsitakse

* Tööd on toetanud riikliku programmi “Eesti keele keeletehnoloogiline tugi (2006 - 2010)" projekt “VAKO: Eesti

1 http://www.eki.ee/corpus/ (3.09.2008).

2 http://evkk.tlu.ee (3.09.2008). 
korpusainesest välja kaks ning enam korda esinevad konstruktsioonid, milles on võimalik kasutada vaid kindlaid käändevorme ning mis on tekstiloomes olulised. Analüüsi tulemusena tuuakse välja kirjakeelele ja õppijakeelele omased kollokatsioonilised üksused, tüüpilised grammatilised konstruktsioonid ja nende leksikaalgrammatilised variandid, milles on kasutatud vaid teatud käändevorme. Siit peaks ilmnema, kuivõrd selgelt on eesti kirjakeeles ja õppijakeeles väljendunud seosed grammatiliste vormide ja sageli kasutatavate konstruktsioonide vahel, samuti see, mille poolest nende kahe eesti keele variandi käändekasutusmustrid sarnanevad või erinevad. Lahknevused kirjakeele ja õppijakeele käändekasutuse kontekstieelistustes annavad teavet ka võrreldavate keelevariantide diskursuserinevuste kohta ning toovad esile sel otstarbel kasutatud stereotüüpsed konstruktsioonid. See on aga oluline mitte üksnes pedagoogilistel ja leksikograafilistel eesmärkidel, vaid sünkroonsel tasandil keelesüsteemi sisemiste varjatult kulgevate arengutendentside väljatoomiseks.

\section{Materjal, analūūsi suunad ja vahendid}

Kirjakeele ja õppijakeele võrdlev analüüs piirdub sagedasemate nimisõnade käändevormide kasutamisega. ${ }^{3}$ Sõnade sagedusandmed on võetud "Eesti kirjakeele sagedussõnastiku" tuhande sagedasema sõna ja sõnavormi järjendist (Kaalep, Muischnek 2002) ${ }^{4}$ ning Eesti vahekeele korpuse sõna- ja vormisageduse statistikast. Nende allikate põhjal on kirjakeeles kümme sagedasemat nimisõna aasta, aeg, mees, kroon, sõna, inimene, raha, elu, naine, ema ja õppijakeeles keel, inimene, aeg, elu, sõna, töö, kiri, kultuur, aasta, raha. Et leida esikümne piires kirjakeele ja õppijakeele sõnavormide sagedusloendi ühisosa, mille all mõeldakse kokkulangeva või samalaadse sagedusega sõnapaare, siis tuleb kõigepealt välja jätta need sõnad, mida teise kasutusvariandi sagedusloendi esikümnes ei ole. Niisugune on õppijakeele sagedasem sõna keel, mis ei kuulu kirjakeele kümne ega kahekümnegi sagedasema hulka; samal põhjusel jäävad analüüsist välja kirjakeeles esikümnesse kuuluvad sõnad mees, kroon, naine, ema ja õppijakeeles töö, kiri, kultuur, raha. Sõna aasta on nii kirjakeele kui ka õppijakeele sagedasemate sõnade esikümnes (kirjakeeles sagedusrea eesotsas, õppijakeeles eelviimane ehk üheksas), kuid distants sageduses on selgelt märgatav. Seetõttu tasub kaaluda, kas sõna aasta on mõtet vaadelda sagedusloendite ühisosa all, olgugi et kuuluvus esikümnesse annab selleks formaalse aluse. Käesolevas uurimuses on otsustatud sõna aasta siiski analüüsist välja jätta. Ülejäänud sõnade sagedused on tunduvalt lähedasemad (inimene - kirjakeeles sageduselt kuues ja õppijakeeles teine, aeg - vastavalt teine ja kolmas, elu - kaheksas ja neljas), ühel juhul isegi kokkulangev (sõna mõlemas sagedusjärjendis viiendal kohal). Niisiis on sõnade inimene, elu, aeg ja sõna kasutamine võrreldavates keelevariantides sageduse poolest analoogne ning need sõnad kuuluvad kirjakeele ja õppijakeele samalaadse sagedusega nimisõnade hulka. Nende vormisageduse uurimiseks ja kasutuskontekstide võrdlemiseks kahe korpusainese alusel tuleb eelnevalt tähelepanu pöörata mõningatele olulistele metodoloogilist laadi küsimustele, nagu valimite representatiivsus, võrreldavus, analüüsi suunad ja vahendid. 3 Kuna sagedasemate nimisõnade väljatoomise protseduuri on kirjeldatud artiklis Eslon 2008: 33-35, siis sel küsimu-
sel siinkohal pikemalt ei peatuta, antakse lühiülevaade ega laskuta metoodilist laadi üksikasjadesse.

4 Vt ka http://www.cl.ut.ee/ressursid/sagedused/ (4.09.2008). 


\subsection{Valimite representatiivsus ja võrreldavus}

Kahe erineva korpusainestiku võrdlemine eeldab korpuste representatiivsust ja võrreldavust. Traditsiooniliselt on representatiivsuse tagatiseks peetud ühelt poolt korpuste ja teisalt nende uurimise mitmemõõtmelisust; võrreldavateks on tunnistatud samadel alusprintsiipidel rajanevaid korpusi (vt Atkins, Clear, Ostler 1992, Biber 1993, McEnery, Wilson 2001: 29-32). Samas pole reaalne, et ka kõige järjekindlamalt üles ehitatud tasakaalustatud korpus sisaldaks keele kohta absoluutselt kõike ning vastaks mis tahes uurimistöö eesmärkidele (vt nt Bergh 2005, Volk 2002), eriti puudutab see suletud korpusi. Iseenesest on see küsimus muidugi oluline, ennekõike seoses mitmekeelsete ja paralleelkorpuste uurimisega (vt nt Baker 1995), kuid ühe keele erinevate kasutusvariantide võrdlemisel arvatavasti mitte niivõrd keskne. Näiteks on Ute Römer püüdnud välja selgitada, mis on inglise keele if-lausete kasutamisel normipärane, sest tegelikult on normi ehk standardi mõiste kokkuleppeline ega pruugi kajastada loomulikku keelekasutust, mida haritud emakeelekõneleja aktsepteerib. Võrrelnud if-lauseid kolmes keeleandmestikus (inglise keele õpik, British National Corpus (BNC), saksa emakeelega õppijate inglise vahekeel ehk õppijakeel5), jõuab Römer järeldusele, et "kooli” inglise keel ei ole vastavuses loomuliku keelekasutusega. Seetõttu peab õpikutes ja keeleõppes ümber orienteeruma autentse kirjakeele sellele osale, mis on tavapärane Briti inglise keelele ja mida emakeelevaldaja loomulikus keelekasutuses eelistab (Römer 2007: 355, 358-363). Niisugusele järeldusele aitas U. Römeril tulla ühe keele kolme kasutusvariandi korpustest tulenev analüüs ja võrdlus, ent samas pole ei inglise keele õpik, BNC ega ka inglise õppijakeel samalaadsed ei mahult, adressaadi valikult, tekstiliikide ja registri ega millegi muu poolest. Teistsuguste uurimiseesmärkide puhul tuleb korpusainestiku tasakaalustatus uurimistulemuste adekvaatsusele kahtlemata kasuks, sest korpuspõhine mitmemõõtmeline keelekirjeldus näitab selgemalt keelendi(te) võimalikku varieerumist olenevalt sagedusest näiteks suulises kõnes ja kirjalikes tekstides või siis keelendi(te) diakroonilist ja regionaalset varieerumist, registrierinevusi, tekstiliikidest sõltuvat varieerumist jne. Inglise keele modaalverbide korpuspõhises analüüsis (läbi viidud BNC alusel) on seda kõike kujukalt demonstreerinud Graeme Kennedy (vt Kennedy 2002: 76-86). Sellele vaatamata ollakse seisukohal (nt Xiao, McEnery 2005), et korpuste mitmemõõtmelisuse ja tasakaalustatuse küsimus pole erinevate ainestike võrdlemisel ning uurimistulemuste adekvaatseks tunnistamisel omaette küsimus, sest keelt saab uurida mitte ainult lingvistiliselt ja korpuspõhiselt, vaid ka statistikal rajanevat automaatset formaalset analüüsi rakendades (nt WordSmith Tools, MonoConc, MonoConc Pro, WordCruncher, Raymond Hickey välja töötatud programmid, R Projecti programmide pakett jt). Korpusest otsitakse sõna- ja vormisagedust, statistilisi kollokatsioonilisi üksuseid, konstruktsioone, klastreid jms. Nii on Zhonghua Xiao ja Anthony McEnery väitnud, et üks WordSmith Toolsi programme KeyWords võimaldab võrrelda erinevaid korpusaineseid sama efektiivselt kui representatiivseks ja omavahel võrreldavaks tunnistatud mitmemõõtmelistele korpusuuringutele tuginevad laiahaardelised korpuspõhised uurimused (vt Xiao, McEnery 2005: 62-82). Kadri Muischnek näiteks on statistiliste kollokatsioonide automaatseks tuvastamiseks kasutanud keelest sõltumatu tarkvara SENTA modifi-

5 Mõisteid vahekeel ja õppijakeel kasutatakse siinkohal sünonüümidena. 
katsiooni SENVA, mis on kohandatud eesti keele verbikesksete ühendite leidmiseks (vt Muischnek 2006: 40).

Kuna nii EKI tekstikorpus kui ka EVKK on avatud ehk monitorkorpused, siis on sõnade arv neis erinev ning kasvab pidevalt. Järelikult on nende korpuste põhjal tehtavas keeleanalüüsis mõttekas alustada sellest, et määrata võrreldavate valimite suurus ja hinnata nende usaldusväärsust. Optimaalse suurusega valimi leidmiseks tehti mõlemas korpuses päring nelja sagedasema nimisõna vormikasutuse kohta ning leiti vastavalt 98928 ja 19433 erikäändevormi.

Järgmine samm optimaalse valimi leidmisel oli tekstilõikude arvu piiramine seitsme tuhandega. Kuna igal lõigul on põhimõtteliselt võrdne tõenäosus sellesse valimisse sattuda, siis eespool nimetatud kindla üldkogumi korral (98928 ja 19433 käändevormi) on EKI tekstikorpuse ja EVKK suhtes representatiivne niisugune valim ehk tekstilõikude kogum suurusjärgus 7000, millesse iga üldkogumi objekt ehk tekstilõik satub võrdse tõenäosusega. Kui see osutub võimalikuks, siis saab iga nimetatud suurusjärguga valimi tunnistada antud uurimuse jaoks sobivaks. Et veenduda kahe valimi alusel saadud päringute kokkulangevuses, tehti EKI tekstikorpusest ja EVKK-st kuuajalise vahega ühe ja sama sõna käändevormide ilmnemise kohta kaks erinevat päringut (Päring 1 ja Päring 2). Siinkohal näide EKI tekstikorpuse põhjal tehtud kahest päringust, millest selgub, et sõna inimene käändevormide esinemissagedus kahes erinevas valimis langeb kokku (vt tabel 1).

Tabel 1. Sõna inimene käändevormide sagedus EKI tekstikorpuse valimites

\begin{tabular}{|c|c|c|c|}
\hline Sõnavorm & Päring 1 & Päring 2 & Kääne \\
\hline inimest & 1421 & 1421 & SG.PART \\
\hline inimesed & 1164 & 1165 & PL.NOM \\
\hline inimene & 960 & 964 & SG.NOM \\
\hline inimese & 765 & 766 & SG.GEN \\
\hline inimesi & 704 & 704 & PL.PART \\
\hline inimeste & 598 & 600 & PL.GEN \\
\hline inimestele & 230 & 232 & PL.ALL \\
\hline inimesele & 176 & 177 & SG.ALL \\
\hline inimestel & 137 & 137 & PL.ADS \\
\hline inimesel & 125 & 123 & SG.ADS \\
\hline inimestega & 107 & 107 & PL.KOM \\
\hline inimestest & 106 & 106 & PL.ELAT \\
\hline inimesega & 75 & 75 & SG.KOM \\
\hline inimesest & 55 & 55 & SG.ELAT \\
\hline inimestelt & 29 & 29 & PL.ABL \\
\hline inimeseks & 27 & 27 & SG.TRANS \\
\hline inimesena & 23 & 23 & SG.ESS \\
\hline inimeselt & 19 & 19 & SG.ABL \\
\hline inimeses & 17 & 17 & SG.INES \\
\hline inimestes & 13 & 13 & PL.INES \\
\hline inimeseni & 8 & 9 & SG.TERM \\
\hline inimesteks & 8 & 8 & PL.TRANS \\
\hline inimesteni & 5 & 5 & PL.TERM \\
\hline inimestesse & 0 & 5 & SG.ILL \\
\hline
\end{tabular}


Et olla veendunud, kas nii saadud tulemus on tõepoolest usaldusväärne, kontrolliti Päring 1 ja Päring 2 valimite sarnasust ka Pearsoni $\chi^{2}$ valemiga:

$$
2=\oint_{i=1}^{k} \bigodot^{\left(n_{i}-N_{i}\right)^{2}} \tilde{N}_{i}{ }_{H_{0}}^{2} d t
$$

$\chi^{2}$ valemi abil saab valimites hinnata vahemikus $0-1$ seda, kas erinevus mingites tunnustes on oluline või mitte. Selleks arvutatakse välja teoreetiliselt võimalik vabadusaste (tähistatud suurusega $d f=$ ingl degree of freedom), mille alusel saab määrata valimi olulisustõenäosuse $p$ (probability level), vt tabel 2.

Tabel 2. Valimite sarnasus arvutatuna $x^{2}$ valemi abil

\begin{tabular}{|c|c|c|c|}
\hline Käänded & Päring1 & Päring2 & Kokku \\
\hline \multirow[t]{2}{*}{ SG.PART } & 1421 & 1421 & 2842 \\
\hline & 1419,428 & 1422,572 & \\
\hline \multirow[t]{2}{*}{ PL.NOM } & 1164 & 1165 & 2329 \\
\hline & 1163,212 & 1165,788 & \\
\hline \multirow[t]{2}{*}{ SG.NOM } & 960 & 964 & 1924 \\
\hline & 960,9358 & 963,0642 & \\
\hline \multirow[t]{2}{*}{ SG.GEN } & 765 & 766 & 1531 \\
\hline & 764,6531 & 766,3469 & \\
\hline \multirow[t]{2}{*}{ PL.PART } & 704 & 704 & 1408 \\
\hline & 703,2212 & 704,7788 & \\
\hline \multirow[t]{2}{*}{ PL.GEN } & 598 & 600 & 1198 \\
\hline & 598,3373 & 599,6627 & \\
\hline \multirow[t]{2}{*}{ PL.ALL } & 230 & 232 & 462 \\
\hline & 230,7445 & 231,2555 & \\
\hline \multirow[t]{2}{*}{ SG.ALL } & 176 & 177 & 353 \\
\hline & 176,3047 & 176,6953 & \\
\hline \multirow[t]{2}{*}{ PL.ADS } & 137 & 137 & 274 \\
\hline & 136,8484 & 137,1516 & \\
\hline \multirow[t]{2}{*}{ SG.ADS } & 125 & 123 & 248 \\
\hline & 123,8628 & 124,1372 & \\
\hline \multirow[t]{2}{*}{ PL.KOM } & 107 & 107 & 214 \\
\hline & 106,8816 & 107,1184 & \\
\hline \multirow[t]{2}{*}{ PL.ELAT } & 106 & 106 & 212 \\
\hline & 105,8827 & 106,1173 & \\
\hline \multirow[t]{2}{*}{ SG.KOM } & 75 & 75 & 150 \\
\hline & 74,91703 & 75,08297 & \\
\hline \multirow[t]{2}{*}{ SG.ELAT } & 55 & 55 & 110 \\
\hline & 54,93915 & 55,06085 & \\
\hline \multirow[t]{2}{*}{ PL.ABL } & 29 & 29 & 58 \\
\hline & 28,96792 & 29,03208 & \\
\hline \multirow[t]{2}{*}{ SG.TRANS } & 27 & 27 & 54 \\
\hline & 26,97013 & 27,02987 & \\
\hline \multirow[t]{2}{*}{ SG.ESS } & 23 & 23 & 46 \\
\hline & 22,97456 & 23,02544 & \\
\hline \multirow[t]{2}{*}{ SG.ABL } & 19 & 19 & 38 \\
\hline & 18,97898 & 19,02102 & \\
\hline \multirow[t]{2}{*}{ SG.INES } & 17 & 17 & 34 \\
\hline & 16,98119 & 17,01881 & \\
\hline \multirow[t]{2}{*}{ PL.INES } & 13 & 13 & 26 \\
\hline & 12,98562 & 13,01438 & \\
\hline
\end{tabular}




\begin{tabular}{|l|r|r|c|}
\hline SG.TERM & 8 & 9 & 17 \\
\hline & 8,490597 & 8,509403 & 16 \\
\hline PL.TRANS & 8 & 8 & 10 \\
\hline & 7,99115 & 8,00885 & 5 \\
\hline PL.TERM & 5 & 5 & \\
\hline SG.ILL & 4,994469 & 5,005531 & $\mathbf{1 3 5 5 9}$ \\
\hline & 0 & 5 & \\
\hline Kokku & 2,497234 & $\mathbf{6 7 7 0 2 7 6 6}$ & \\
\hline Pearson's $x^{2}$ statistic & 5,082593 & $\mathbf{6 7 8 7}$ & \\
\hline df & 23 & & \\
\hline$p$ & 0,999967 & & \\
\hline
\end{tabular}

Tabelis 2 esitatud andmed näitavad, et vabadusastme $d f=23$ puhul on olulisustõenäosus $p=0,999967$, mis tähendab, et kahe erineva päringu tulemused on sarnased. Seega on EKI tekstikorpuse 700o lõigust koosnev valim ja EVKK 7000 lõigust koosnev valim nelja sagedasema nimisõna käändegrammatika võrdlevaks uurimiseks suurusjärgult piisavad.

\subsection{Analūūsi suunad}

Selle alusel, kuidas korpusi on keele uurimisel kasutatud, eristatakse kaht peamist suunda: ühelt poolt korpuspõhist keeleanalüüsi (ingl corpus-based language analysis) ja teisalt korpusest tulenevat uurimist (corpus-driven research). Kõige üldisema seletuse järgi on korpuspõhise analüüsi puhul korpuse keeleaines uurija jaoks allikmaterjal, millest vastavalt püstitatud uurimiseesmärgile vajalikku teavet saada. Elena Tognini Bonelli on kirjutanud, et seejuures kasutab uurija korpust kui keelekirjelduste ja teooriate paikapidavuse tõendusmaterjali: “.. use of a corpus as evidence for language description is usually referred to as corpus-based" (Tognini Bonelli 2002: 73). Selline lähenemisviis korpustele on olnud traditsiooniline inglise keele sõnavara uurimisel nii leksikograafilistel kui ka peadagoogilistel eesmärkidel (vt Kennedy 1999: 108-121). Alates H. M. Palmerist, J. R. Firthist ja M. A. K. Halliday'st on sõna tähendust peetud sõltuvaks nii leksikaalgrammatilisest kui ka ekstralingvistilisest kontekstist (sotsiaalne keskkond, keelenormid jms), milles sõnakasutus ilmneb (vt McEnery, Wilson 2001: 23-24). John Sinclairi (1991) järgi on sõna tähenduse kujunemise aluseks semantika ja grammatika koosmõju kindlat tüüpi konstruktsioonides, fraasides ja lausetes. Seega on sõna tähendus olemuselt tekstuaalne nähtus, mis on kirjeldatav keelesüsteemi süntagmaatilisel tasandil. Analoogselt on uuritud ka grammatiliste vormide ja konstruktsioonide kasutust. Näiteks Sylviane Grangerit on huvitanud, kuidas inglased ja edasijõudnud inglise keele kui võõrkeele õppijad oma akadeemilist laadi kirjutistes partitsiipi kasutavad. Vastuse saamiseks on ta leidnud näitelaused kahest erinevast korpusainestikust, seejärel neid lauseid lingvistiliselt analüüsinud ning saadud tulemusi võrrelnud (Granger 1997: 185-198).

Korpusest tulenev keeleainese uurimine esindab vastupidist suunda: korpus ei ole siin teooriate tõestamiseks mõeldud tekstikogu, vaid keeleaines, millel on võimalik rakendada erinevaid automaatseid programme ning statistilise analüüsi meetodeid ja saada põhimõtteliselt erinevat ning mõneti ootamatut teavet, mis 
traditsioonilises korpuspõhises lingvistilises analüüsis ei eksplitseeru, kuid mis on omane loomulikule keelekasutusele ning just seetõttu huvipakkuv ${ }^{6}$. Uudsus seisneb selles, et traditsioonilist lingvistilist uurimisainest analüüsitakse mittelingvistiliselt ja formaalselt. Seejuures ei pea korpus olema märgendatud, piisab elektroonilisest tekstiarhiivist. Mittelingvistiline lähenemine keeleainesele on nii empiirika kui ka keeleteooria seisukohalt innovaatiline, kuna võimaldab lingvistil leida uusi lahendusi seni raskesti kirjeldatavatele keelesüsteemi nähtustele. Näiteks on Tognini Bonelli rõhutanud, et korpusest tulenev keeleuuring võimaldab ületada veelahkme leksika ja grammatika vahel, ühendades need kaks keelesüsteemi osa süntagmaatiliseks tervikuks (Tognini Bonelli 2002: 75). Nadja Nesselhauf kirjutab sagedusel põhinevatest erineva varieerumisvabadusega süntaktilistest ja semantilistest terviküksustest (Nesselhauf 2005: 21). Iga sõnavorm tuleb esile vaid talle omastes kasutuskontekstides, mille alusel saab välja tuua erineva pikkuse ja sünonüümireaga kollokatsioonilisi leksikaalseid üksuseid. Näiteks inglise keele sünonüümide pretty ja handsome kasutuspiirangud ehk tüüpilised kontekstid on ühelt poolt pretty girl, boy, woman, flower, garden, colour, village ja teisalt handsome boy, man, car, vessel, overcoat, airliner, typewriter (vt Leech 1981: 17). Neid kollokatsioonilisi üksuseid kasutatakse kui terviklikke konstruktsioone. Sellistena on nad tavapärased, üldkasutatavad, osati hinnangulisust edastavad ja pooleldi idiomaatilised. ${ }^{7}$ Kui kasutuspiirangutest pole kinni peetud, siis on tegu ebatüüpiliste kollokatsiooniliste üksustega, mille ilmnemisel on oma kindlad põhjused: näiteks suhtlussituatsioonist tulenev või isikupärane keeleloome ja registrivalik, keeleõppija või tõlkija normivastane või laiemalt - mitteaktsepteeritav sõnakasutus jm. Sõnavormide kasutuskontekstide valik võib olla piiratud ka teatud leksikaalgrammatilise rühma, grammatiliste kategooriate ja vormide varieerumisega (süntaktilised sünonüümid).

Keeleüksuste automaatne väljatoomine korpusainestikust võimaldab leida konstruktsioone, milles üht ja sama vormi on vähemalt kahel korral samas ümbruses kasutatud. Nende võrdlemisel ilmnevad sageli kasutatud konstruktsioonide leksikaalsed ja leksikaalgrammatilised variandid. Ingliskeelsetes allikates on niisuguseid konstruktsioonide kogumeid nimetatud keelendite kasutusmustriteks või -mallideks (ingl patterns), mida on peetud olulisteks keeleõppe, sõnastike ja grammatikate tarvis (vt nt Granger 1998: 145, Hanston 2002: 167, Römer 2005, Nesselhauf, Römer 2007). Näiteks EVKK-s kasutatakse sõna inimene ainsuse nominatiiviga sagedasti loogilist implikatsiooni kui inimene on. Sel lingvistilisel konstruktsioonil on õppijakeeles hulk leksikaalseid (kui inimene tahab, kogeb, elab, suhtleb) ning leksikaalgrammatilisi variante (et inimene peab ja kui (et kui, sest kui) inimene (peab) või inimene peab olema (maksma, teadma) inimene võib töötada inimene ei saa (ei ole) või haritud (iga) inimene peab saab, võib, tahab), mis kujutavad endast sõna inimene ühte eesti õppijakeelele omast ainsuse nominatiiviga kasutusmustrit. Kasutusmustri dominandiks on konstruktsioon kui inimene on, mida selle leksikaalgrammatiliste variantidega võrreldes on korpuses kõige sagedamini kasutatud.

\footnotetext{
6 Väga huvitavaid tulemusi on andnud teksti ideoloogia, suunitluse, allteksti mõistmise ning autori mõttelaadi ja eelistuste avamisel korpusest tulenev diskursusanalüüs (vt Stubbs 1996, Orpin 2005, Hoey jt 2007). Seda suunda on essee kui tekstitüübi määramisel rakendanud ka Heidi Meier (2003).

7 Sünonüümide kasutuspiirangutest soome keeles vt Jantunen 2004; eesti keele verbikesksete püsiühendite idioomide, poolidiomaatiliste ja kollokatiivsete mitmesõnaliste ühendite analüüsi vt Muischnek 2006; sageduse alusel esile tulevaid kollokatsioone loomulikus keelekasutuses ja inglise õppijakeeles on võrreldud monograafias Nesselhauf 2005.
} 


\subsection{Analúūsi vahendid}

Kirjakeele ja õppijakeele nelja sagedasema nimisõna inimene, elu, aeg ja sõna käändevormide sageduse ja kasutuskontekstide väljatoomiseks ning võrdlemiseks on käesolevas uurimuses rakendatud programmi WordSmith Tools 5,o (arendaja Mike Scott), mis on üks tunnustatumaid tekstitöötlusvahendeid maailmas (vt Scott, Tribble 2006). ${ }^{8}$ Viimasel ajal propageeritakse John M. Chambersi (2007) arendatavat rikkalike visualiseerimisvõimalustega vabavaralist statistikapaketti "The R Project for Statistical Computing".

WordSmith Tools sisaldab kolme programmi, mille abil saab korpuse sõnavara sagedusloendi (Word List), konkordantsid ehk grammatiliste vormide kasutuskontekstid (Concord) ja võtmesõnade võrdluse (KeyWords). Kui tegu on lemmatiseerimata korpusega (nagu EKI tekstikorpus ja EVKK), siis võib analüüsitavate sõnade grammatilised vormid Word Listi alusel ühte koondada ja sel teel tuua välja lemmad.

Grammatiliste vormide kasutuskontekstid annab programmi Concord rakendamine. Konkordantside alusel võib välja tuua sõnavormide kasutusmustrid ja saada andmed kindlate grammatiliste konstruktsioonide tavapärasuse ning nende võimalike leksikaalgrammatiliste variantide kohta korpusainestikus. Programm Concord lubab automaatselt rakendada ka tekstilõigu pikkuse piirangut, mis on oluline eesti keele grammatilise homonüümia probleemi lahendamisel, eriti ühendverbi ja nimisõna käändevormide eristamisel. Artiklis analüüsitavate sõnade puhul on vormihomonüümia seotud sõnadega elu, aeg ja sõna: näiteks sõnavormi elu puhul on küsimus grammatiliste käänete eristamisest, vorm elus on määratav kas nimisõna ainsuse inessiivi või omadussõnana, mille vastandsõna on surnud; sõnavorm aja on kas ainsuse genitiiv või käskiv kõneviis verbidest ajama, naerma ajama, minema ajama jt; ajad on kas nimisõna mitmuse nominatiivi vorm või indikatiivi oleviku ainsuse 2. pööre (mis juttu sa ajad); sõnas - kas ainsuse inessiivi vorm või imperfekti ainsuse 3. pööre. EKI tekstikorpuse ja EVKK valimite vormihomonüümia väljaselgitamiseks oli Concordi tekstilõigu pikkus täiesti piisav. Siinkohal lühike näide EKI tekstikorpuse konkordantsist sõnavormiga ajas; näidetes (3) ja (5-7) on kasutatud nimisõna aeg ainsuse inessiivi vormis ja ülejäänud juhtudel on tegu verbiga indikatiivi imperfekti ainsuse 3. pöördes:

(1) nagu poleks midagi juhtunud, ajas käed ja jalad laiali ning kordas

(2) voolas särgi alla, krae vahele, ajas vastikult lõdisema

(3) Ma ei oska asju

(4) natuke suurem kui vaja ja see

ajas ritta panna.

(5) arhitektuur elab muutuste

ajas natuke hirmu nahka

(6) ja kiirelt muutuvas

ajas. Lätlaste Sandra Levane

ajas. Arvestatavaks ehituskunsti

(7) "Felixi” toodang asendab praeguses ajas Eesti lastele Campbelli supipurke.

Analüüsis loobuti automaatsest morfoloogilisest ühestamisest, sest käsitsi ühestamine, olgugi et töömahukam, annab täpsema tulemuse. Kui aga eesmärk oli sõnavormide kasutusmustrite esiletoomine, siis piirati tekstilõik kolme üksusega, nt tol ajal oli, sellel ajal oli, sellel ajal on, sel ajal tekkis jne. Antud juhul on

8 Kasutada võib ka teisi samalaadseid programme, nt MonoConc, MonoConc Pro (Randi Reppeni vördlust WordSmith Toolsiga vt http://llt.msu.edu/vol5num3/review4/default.html, 12.10.2008).

9 Vt http://www.r-project.org/ (12.10.2008). 
konstruktsiooni ajamäärus + verbivorm indikatiivis leksikaalgrammatilised variandid reastatud esinemissageduse alusel, mis neil on EVKK-s (vastavalt 18, 12, 6 ja 5 korda). Konstruktsiooni identifitseerimiseks kasutati eesti keele süntaksianalüsaatorit, mille väljundit töödeldi spetsiaalselt programmeeritud makrode abil. Tänu sellele oli võimalik üles leida samalaadselt analüüsitud konstruktsioonid, milleks antud juhul on //_P_dem sg ad \#cap // ${ }^{* *}$ CLB @ NN> //_S_com sg ad \#cap // @ ADVL//_V_main indic imp ps3 sg ps af \#cap \#FinV \#Intr // @+FMV. ${ }^{10}$ Niisugune lähenemisviis võimaldas sorteerida nelja sagedasema nimisõna kolmest üksusest koosnevaid konstruktsioone käändevormide alusel ning siduda käändevormide kasutamise kindlat liiki konstruktsioonide ja nende leksikaalgrammatiliste variantidega. Kirjakeele ja õppijakeele korpusainestiku alusel saadud andmete edasine võrdlus toob esile teatud käändevormide kasutuseelistused kindlat liiki konstruktsioonides.

Programmi KeyWords rakendamine annab sõnade olulisuse nende sageduse põhjal ning sobib seetõttu kahe keeleainese võrdlemiseks. Kuna programm arvestab keeleüksusi, mille minimaalne sagedus korpuses on kaks korda, siis on programmi abil välja toodud keeleaines mahukas. Seetõttu piirdutakse valimiga 50\% materjalist + 1 (vt Berber-Sardinha 1999). Kuna siinne uurimus on esialgne, siis piirdutakse "Eesti kirjakeele sagedussõnastiku" ja EVKK statistikamooduli alusel kindlaks määratud nelja sagedasema nimisõna analüüsiga, mistõttu kahe valimi käändevormide statistilise sarnasuse või erinevuse esiletoomiseks on otstarbekam kasutada alternatiivset võimalust $-\chi^{2}$ testi $2 \times 2$ tabelis. See tähendab, et iga käände kohta koostatakse tabel, mis näitab otsitava vormi sageduse suhet kahes erinevas valimis ülejäänud käändevormide arvuga, osutades käändevormi esindatusele (vt tabel 3).

Tabel 3. 2 × 2 tabeli näide

\begin{tabular}{|l|c|c|}
\hline & Otsitava käände sagedus & Ülejäänud käändevormide arv valimis \\
\hline EKI tekstikorpus & $\mathrm{a}$ & $\mathrm{b}$ \\
\hline EVKK & $\mathrm{c}$ & $\mathrm{d}$ \\
\hline
\end{tabular}

$\chi^{2}$ arvutamiseks kasutatakse valemit

$$
\chi^{2}=\frac{(n-1)(a d-b c)^{2}}{(a+b)(a+c)(b+d)(c+d)}
$$

kus $\mathrm{n}=\mathrm{a}+\mathrm{b}+\mathrm{c}+\mathrm{d}$.

$\chi^{2}$ kriitiline väärtus on 5,02 , mis antud juhul määrab käändevormide esinemise sarnasuse/erinevuse kahes valimis tõenäosusega $5 \%$. Kui käändevorm pole valimis esindatud, siis $\chi^{2}$ ei arvutata. Kui saadud $\chi^{2}$ on kriitilisest väärtusest väiksem, siis on käändekasutus kahes valimis sarnane (vt tabel 4). Mida suurem on $\chi^{2}$ kriitilisest väärtusest, seda suurem on kahe valimi erinevus käändevormi kasutamisel.

10 Eesti keele kitsenduste grammatika süntaksianalüsaatori märgendite kohta vt http://math.ut.ee/ kaili/papers/ 
Tabel 4. Sõna inimene käändekasutuse sarnasus/erinevus EKI tekstikorpuses ja EVKK-s

\begin{tabular}{|c|c|c|c|c|c|}
\hline \multirow{2}{*}{ Käänded } & \multicolumn{2}{|c|}{ EKI tekstikorpus } & \multicolumn{2}{|c|}{ EVKK } & \multirow[b]{2}{*}{$x^{2}$} \\
\hline & $\mathbf{a}$ & b & c & d & \\
\hline SG.NOM & 960 & 5812 & 1257 & 3583 & 254,20 \\
\hline PL.NOM & 1164 & 5608 & 1117 & 3723 & 62,03 \\
\hline SG.GEN & 765 & 6007 & 359 & 4481 & 48,58 \\
\hline PL.GEN & 598 & 6174 & 363 & 4477 & 6,58 \\
\hline SG.PART & 1421 & 5351 & 397 & 4443 & 349,15 \\
\hline PL.PART & 704 & 6068 & 374 & 4466 & 23,86 \\
\hline SG.ILL & 0 & 6772 & 0 & 4840 & - \\
\hline PL.ILL & 0 & 6772 & 0 & 4840 & - \\
\hline SG.INES & 17 & 6755 & 11 & 4829 & 0,07 \\
\hline PL.INES & 13 & 6759 & 7 & 4833 & 0,37 \\
\hline SG.ELAT & 55 & 6717 & 43 & 4797 & 0,20 \\
\hline PL.ELAT & 106 & 6666 & 40 & 4800 & 12,41 \\
\hline SG.ALL & 176 & 6596 & 90 & 4750 & 6,89 \\
\hline PL.ALL & 230 & 6542 & 150 & 4690 & 0,79 \\
\hline SG.ADS & 125 & 6647 & 137 & 4703 & 12,41 \\
\hline PL.ADS & 137 & 6635 & 155 & 4685 & 16,02 \\
\hline SG.ABL & 19 & 6753 & 22 & 4818 & 2,43 \\
\hline PL.ABL & 29 & 6743 & 0 & 4840 & 20,78 \\
\hline SG.TRANS & 27 & 6745 & 34 & 4806 & 4,98 \\
\hline PL.TRANS & 8 & 6764 & 0 & 4840 & 5,72 \\
\hline SG.TERM & 8 & 6764 & 0 & 4840 & 5,72 \\
\hline PL.TERM & 5 & 6767 & 0 & 4840 & 3,57 \\
\hline SG.ESS & 23 & 6749 & 16 & 4824 & 0,01 \\
\hline PL.ESS & 0 & 6772 & 0 & 4840 & - \\
\hline SG.ABES & 0 & 6772 & 0 & 4840 & - \\
\hline PL.ABES & 0 & 6772 & 0 & 4840 & - \\
\hline SG.KOM & 75 & 6697 & 43 & 4797 & 1,35 \\
\hline PL.KOM & 107 & 6665 & 225 & 4615 & 95,70 \\
\hline Kokku & 6772 & & 4840 & & \\
\hline
\end{tabular}

Tabelis 4 toodud andmete alusel on EKI tekstikorpuse ja EVKK suurem erinevus sõna inimene käändevormide kasutuses seotud järgmiste käänetega: ainsuse partitiiv 349,15 ja nominatiiv 254,20 - mitmuse komitatiiv 95,70 ja nominatiiv 62,03 - ainsuse genitiiv 48,58 - mitmuse partitiiv 23,86 ja ablatiiv 20,78 jne. Suurem sarnasus ilmneb ainsuse essiivi 0,01, inessiivi 0,07 ja elatiivi 0,20 - mitmuse inessiivi 0,37 ja allatiivi 0,79 - ainsuse komitatiivi 1,35 ja ablatiivi 2,43 - mitmuse terminatiivi 3,57 ja ainsuse translatiivi 4,98 kasutuses. Sagedusandmete statistiliseks töötlemiseks rakendati Exeli tabelarvutust ja graafilisi võimalusi, milles kahe korpuse vaheline käändevormide dünaamika kujukalt esile tuleb (vt joonis 1).

Statistikast nähtub, mis on eesti keele käändevormide sagedusele iseloomulik ning missuguseid leksikaalsemantilisi ja paradigmaatilisi arenguid erinevate keelevariantide vahel võib käändegrammatikas täheldada. Analüüsi tulemused nagu ka erinevused EKI tekstikorpuse ja EVKK käändevormide sageduses on toodud protsentides tabelis 5 . 


\section{INIMENE}

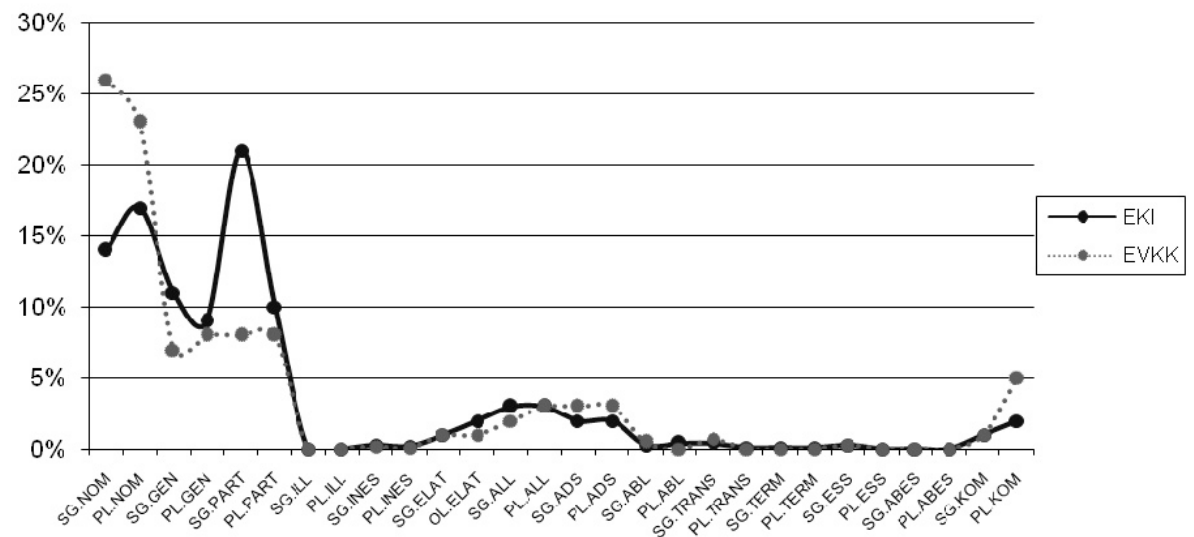

Joonis 1. Sõna inimene käändevormide sagedus EKI tekstikorpuses ja EVKK-s

Tabel 5. Erinevused sõna inimene grammatiliste käänete sageduses

\begin{tabular}{|c|c|c|c|c|c|}
\hline Kääne & EKI tekstikorpus & Sagedus & EVKK & Sagedus & Erinevus \\
\hline SG.NOM & $14 \%$ & 960 & $26 \%$ & 1257 & $12 \%$ \\
\hline PL.NOM & $17 \%$ & 1164 & $23 \%$ & 1117 & $6 \%$ \\
\hline SG.GEN & $11 \%$ & 765 & $7 \%$ & 359 & $4 \%$ \\
\hline PL.GEN & $9 \%$ & 598 & $8 \%$ & 363 & $1 \%$ \\
\hline SG.PART & $21 \%$ & 1421 & $8 \%$ & 397 & $13 \%$ \\
\hline PL.PART & $10 \%$ & 704 & $8 \%$ & 374 & $2 \%$ \\
\hline SG.ILL & $0 \%$ & 0 & $0 \%$ & 0 & $0 \%$ \\
\hline PL.ILL & $0 \%$ & 0 & $0 \%$ & 0 & $0 \%$ \\
\hline SG.INES & $0,3 \%$ & 17 & $0,2 \%$ & 11 & $0 \%$ \\
\hline PL.INES & $0,2 \%$ & 13 & $0,1 \%$ & 7 & $0 \%$ \\
\hline SG.ELAT & $1 \%$ & 55 & $1 \%$ & 43 & $0 \%$ \\
\hline PL.ELAT & $2 \%$ & 106 & $1 \%$ & 40 & $1 \%$ \\
\hline SG.ALL & $3 \%$ & 176 & $2 \%$ & 90 & $1 \%$ \\
\hline PL.ALL & $3 \%$ & 230 & $3 \%$ & 150 & $0 \%$ \\
\hline SG.ADS & $2 \%$ & 125 & $3 \%$ & 137 & $1 \%$ \\
\hline PL.ADS & $2 \%$ & 137 & $3 \%$ & 155 & $1 \%$ \\
\hline SG.ABL & $0,3 \%$ & 19 & $0,5 \%$ & 22 & $0 \%$ \\
\hline PL.ABL & $0,4 \%$ & 29 & $0,0 \%$ & 0 & $0 \%$ \\
\hline SG.TRANS & $0,4 \%$ & 27 & $0,7 \%$ & 34 & $0 \%$ \\
\hline PL.TRANS & $0,1 \%$ & 8 & $0 \%$ & 0 & $0 \%$ \\
\hline SG.TERM & $0,1 \%$ & 8 & $0 \%$ & 0 & $0 \%$ \\
\hline PL.TERM & $0,1 \%$ & 5 & $0 \%$ & 0 & $0 \%$ \\
\hline SG.ESS & $0,3 \%$ & 23 & $0,3 \%$ & 16 & $0 \%$ \\
\hline PL.ESS & $0 \%$ & 0 & $0 \%$ & 0 & $0 \%$ \\
\hline SG.ABES & $0 \%$ & 0 & $0 \%$ & 0 & $0 \%$ \\
\hline PL.ABES & $0 \%$ & 0 & $0 \%$ & 0 & $0 \%$ \\
\hline SG.KOM & $1 \%$ & 75 & $1 \%$ & 43 & $0 \%$ \\
\hline PL.KOM & $2 \%$ & 107 & $5 \%$ & 225 & $3 \%$ \\
\hline
\end{tabular}




\section{Käändevormide statistika eesti kirjakeeles ja õppijakeeles}

\subsection{Sõna inimene käändevormide statistika}

Sõna inimene käändevormide statistikas ilmneb ühelt poolt eesti keele grammatiliste ja semantiliste käänete vastandatus ja teisalt semantiliste käänete kokkulangev või samalaadne kasutus nii kirjakeeles kui ka õppijakeeles.

Erinevus grammatiliste ja semantiliste käänete vastandatuses seisneb vaid selles, et õppijakeele sagedasemad vormid on ainsuse (26\%) ja mitmuse nominatiiv (23\%), samas kui kirjakeeles on sagedasem ainsuse partitiiv (21\%). Kõige suurem erinevus EKI tekstikorpuse ja EVKK valimite vahel ongi grammatiliste käänete sageduses: ainsuse nominatiivi puhul 12\% ning partitiivi puhul 13\% (vt tabel 5 ning joonis 1). Võrreldes kirjakeelega on õppijakeeles ainsuse nominatiivi selgelt ülekasutatud.

Semantilistest käänetest pole nii kirjakeeles kui ka õppijakeeles kasutatud ainsuse ja mitmuse illatiivi, mitmuse essiivi, ainsuse ja mitmuse abessiivi. See võib olla seletatav teatud loogilise vastuoluga sõna semantika ja vormi grammatilise tähenduse vahel. Õppijakeeles puuduvad ka mitmuse translatiivi, ainsuse ning mitmuse ablatiivi ja terminatiivi vormid. Kirjakeeleski tulevad need käändevormid äärmiselt harva ette (vaid o,1\% valimi kohta). Nii kirjakeeles kui ka õppijakeeles oli väga harva ainsuse (vastavalt $0,3 \%$ ja $0,2 \%)$ ja mitmuse inessiivi $(0,2 \%$ ja $0,1 \%)$, ainsuse ablatiivi ( $0,3 \%$ ja $0,5 \%)$, translatiivi $(0,4 \%$ ja $0,7 \%)$ ja essiivi $(0,3 \%$ ja $0,3 \%)$. Harva esines ainsuse ( $1 \%$ ja $1 \%)$ ja mitmuse ( $2 \%$ ja $1 \%$ ) elatiivi; ainsuse ( $3 \%$ ja $2 \%$ ) ja mitmuse ( $3 \%$ ja $3 \%$ ) allatiivi; ainsuse (2\% ja $3 \%$ ) ja mitmuse (2\% ja $3 \%$ ) adessiivi; ainsuse komitatiivi (1\% ja 1\%). Toodud statistilised andmed näitavad, et semantiliste käänete sagedus langeb kirjakeeles ja õppijakeeles kokku või on samalaadne. Mõneti eraldiseisvaks jääb mitmuse komitatiiv (vastavalt $2 \%$ ja $5 \%$ ), kuid ilmselt on siin tegu eesti keelele omase nähtusega, sest ka nimisõnade elu ja sõna käändevormide statistika näitab (vt allpool), et tavapäraselt on komitatiivi sagedus ülejäänud semantiliste käänete sagedusest kõrgem.

\subsection{Sõna elu käändevormide statistika}

Sõna elu käändevormide suuremad erinevused EKI tekstikorpuses ja EVKK-s on seotud semantiliste käänete ainsuse vormidega: komitatiiv 111,17 - inessiiv 93,88 terminatiiv 61,10 - allatiiv 34,52 - elatiiv 32,81 - abessiiv 24,39 - illatiiv 13,15 jt. Sarnasus on ainsuse genitiivi 1,10 ja mitmuse partitiivi 4,98 puhul (vt tabel 6). Seda ei saa tõlgendada nii, nagu võiks sõna elu käändevormide statistika põhjal rääkida grammatiliste ja semantiliste käänete selgest vastandatusest; rääkida saab kirjakeele ja õppijakeele käändeparadigmade sünkroonsusest. 
Tabel 6. Sõna elu käändekasutuse sarnasus/erinevus EKI tekstikorpuses ja EVKK-s

\begin{tabular}{|c|c|c|c|c|c|}
\hline \multirow{2}{*}{ Käänded } & \multicolumn{2}{|c|}{ EKI tekstikorpus } & \multicolumn{2}{|c|}{ EVKK } & \multirow[b]{2}{*}{$x^{2}$} \\
\hline & $\mathbf{a}$ & b & c & d & \\
\hline SG.NOM & 184 & 1028 & 225 & 979 & 5,28 \\
\hline PL.NOM & 8 & 1204 & 0 & 1204 & 7,97 \\
\hline SG.GEN & 159 & 1053 & 141 & 1063 & 1,10 \\
\hline PL.GEN & 0 & 1212 & 0 & 1204 & \\
\hline SG.PART & 81 & 1131 & 122 & 1082 & 9,34 \\
\hline PL.PART & 5 & 1207 & 0 & 1204 & 4,98 \\
\hline SG.ILL & 0 & 1212 & 13 & 1191 & 13,15 \\
\hline PL.ILL & 0 & 1212 & 0 & 1204 & - \\
\hline SG.INES & 324 & 888 & 550 & 654 & 93,88 \\
\hline PL.INES & 0 & 1212 & 0 & 1204 & - \\
\hline SG.ELAT & 206 & 1006 & 110 & 1094 & 32,81 \\
\hline PL.ELAT & 0 & 1212 & 0 & 1204 & - \\
\hline SG.ALL & 58 & 1154 & 10 & 1194 & 34,52 \\
\hline PL.ALL & 0 & 1212 & 0 & 1204 & - \\
\hline SG.ADS & 12 & 1200 & 0 & 1204 & 11,98 \\
\hline PL.ADS & 0 & 1212 & 0 & 1204 & - \\
\hline SG.ABL & 8 & 1204 & 0 & 1204 & 7,97 \\
\hline PL.ABL & 0 & 1212 & 0 & 1204 & - \\
\hline SG.TRANS & 0 & 1212 & 9 & 1195 & 9,09 \\
\hline PL.TRANS & 0 & 1212 & 0 & 1204 & - \\
\hline SG.TERM & 60 & 1152 & 0 & 1204 & 61,10 \\
\hline PL.TERM & 0 & 1212 & 0 & 1204 & - \\
\hline SG.ESS & 0 & 1212 & 0 & 1204 & - \\
\hline PL.ESS & 0 & 1212 & 0 & 1204 & - \\
\hline SG.ABES & 0 & 1212 & 24 & 1180 & 24,39 \\
\hline PL.ABES & 0 & 1212 & 0 & 1204 & - \\
\hline SG.KOM & 107 & 1105 & 0 & 1204 & 111,17 \\
\hline PL.KOM & 0 & 1212 & 0 & 1204 & - \\
\hline Kokku & 1212 & & 1204 & & \\
\hline
\end{tabular}

Esiteks on sõna elu käändevormide moodustamises teatud loogilis-grammatilised piirangud, mis tulenevad sõna semantikast. Ilmselt seetõttu puuduvad mõlemas eesti keele kasutusvariandis mitmuse genitiivi, illatiivi, inessiivi, elatiivi, allatiivi, adessiivi, ablatiivi, translatiivi, terminatiivi, abessiivi, komitatiivi ning ainsuse ja mitmuse essiivi vormid (vt tabel 7). EVKK-s pole kasutatud ka sõna elu mitmuse nominatiivi, ainsuse adessiivi, ablatiivi, terminatiivi ja komitatiivi, samas kui EKI tekstikorpuse valimis oli nimetatud vorme vastavalt $1 \%, 1 \%, 1 \%, 5 \%$ ja $9 \%$. Seega on õppijakeeles alakasutatud ainsuse komitatiivi ja terminatiivi.

Tabel 7. Erinevused sõna elu käändevormide sageduses

\begin{tabular}{|l|c|c|c|c|c|}
\hline Käänded & EKI tekstikorpus & Sagedus & EVKK & Sagedus & Erinevus \\
\hline SG.NOM & $15 \%$ & 184 & $19 \%$ & 225 & $4 \%$ \\
\hline PL.NOM & $1 \%$ & 8 & $0 \%$ & 0 & $1 \%$ \\
\hline SG.GEN & $13 \%$ & 159 & $12 \%$ & 141 & $1 \%$ \\
\hline PL.GEN & $0 \%$ & 0 & $0 \%$ & 0 & $0 \%$ \\
\hline SG.PART & $7 \%$ & 81 & $10 \%$ & 122 & $3 \%$ \\
\hline
\end{tabular}




\begin{tabular}{|l|r|r|r|r|c|}
\hline PL.PART & $0,4 \%$ & 5 & $0 \%$ & 0 & $0 \%$ \\
\hline SG.ILL & $0 \%$ & 0 & $1 \%$ & 13 & $1 \%$ \\
\hline PL.ILL & $0 \%$ & 0 & $0 \%$ & 0 & $0 \%$ \\
\hline SG.INES & $27 \%$ & 324 & $46 \%$ & 550 & $19 \%$ \\
\hline PL.INES & $0 \%$ & 0 & $0 \%$ & 0 & $0 \%$ \\
\hline SG.ELAT & $17 \%$ & 206 & $9 \%$ & 110 & $8 \%$ \\
\hline PL.ELAT & $0 \%$ & 0 & $0 \%$ & 0 & $0 \%$ \\
\hline SG.ALL & $5 \%$ & 58 & $1 \%$ & 10 & $4 \%$ \\
\hline PL.ALL & $0 \%$ & 0 & $0 \%$ & 0 & $0 \%$ \\
\hline SG.ADS & $1 \%$ & 12 & $0 \%$ & 0 & $1 \%$ \\
\hline PL.ADS & $0 \%$ & 0 & $0 \%$ & 0 & $0 \%$ \\
\hline SG.ABL & $1 \%$ & 8 & $0 \%$ & 0 & $1 \%$ \\
\hline PL.ABL & $0 \%$ & 0 & $0 \%$ & 0 & $0 \%$ \\
\hline SG.TRANS & $0 \%$ & 0 & $1 \%$ & 9 & $1 \%$ \\
\hline PL.TRANS & $0 \%$ & 0 & $0 \%$ & 0 & $0 \%$ \\
\hline SG.TERM & $5 \%$ & 60 & $0 \%$ & 0 & $5 \%$ \\
\hline PL.TERM & $0 \%$ & 0 & $0 \%$ & 0 & $0 \%$ \\
\hline SG.ESS & $0 \%$ & 0 & $0 \%$ & 0 & $0 \%$ \\
\hline PL.ESS & $0 \%$ & 0 & $0 \%$ & 0 & $0 \%$ \\
\hline SG.ABES & $0 \%$ & 0 & $2 \%$ & 24 & $2 \%$ \\
\hline PL.ABES & $0 \%$ & 0 & $0 \%$ & 0 & $0 \%$ \\
\hline SG.KOM & $9 \%$ & 107 & $0 \%$ & 0 & $9 \%$ \\
\hline PL.KOM & $0 \%$ & 0 & $0 \%$ & 0 & $0 \%$ \\
\hline
\end{tabular}

Sünkroonsus avaldub ka käändevormide sageduste samalaadses kõikumises (vt joonis 2). Lahknevused on seotud kindlate vormidega, mis on esindatud mõlema korpuse valimites, kuid mida õppijakeeles on kas üle- või alakasutatud. Nii on ainsuse inessiivi selgelt ülekasutatud (vahe kirjakeelega 19\%), järgnevad ainsuse nominatiiv (vahe 4\%), partitiiv (vahe $3 \%$ ) ja abessiiv (vahe $2 \%$ ), samas kui ainsuse elatiivi (vahe kirjakeelega 8\%) ja allatiivi (vahe 4\%) on alakasutatud.

\section{ELU}

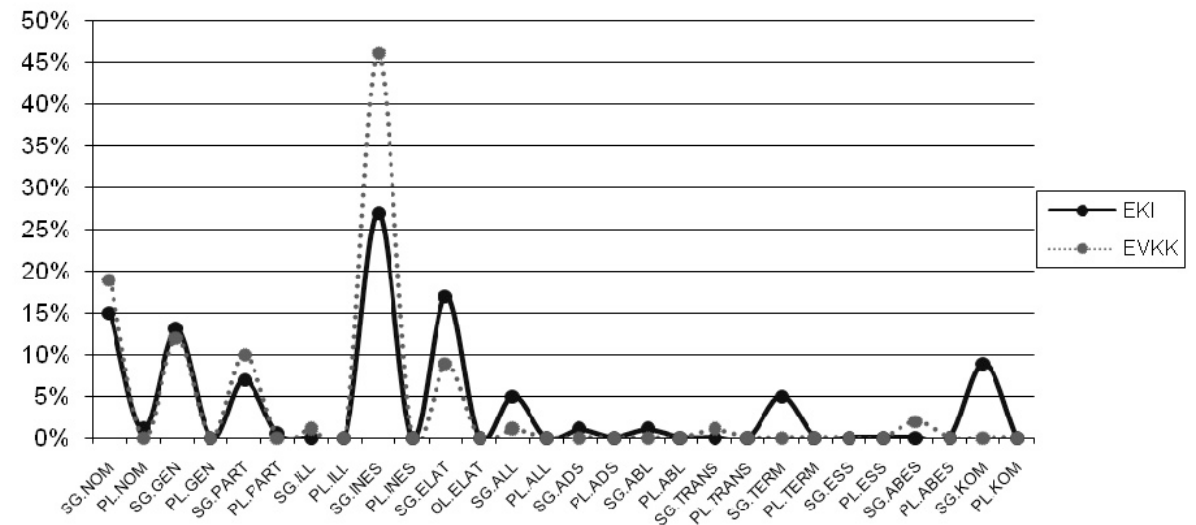

Joonis 2. Sõna elu käändevormide sagedus EKI tekstikorpuses ja EVKK-s 


\subsection{Sõna aeg käändevormide statistika}

Sõna aeg käändevormide kasutuse erinevused EKI tekstikorpuses ja EVKK-s on seotud valdavalt ainsuse adessiiviga 528,81 - vähemal määral mitmuse nominatiivi 138,78 - ainsuse nominatiivi 85,96 - ablatiivi 81,97 - mitmuse genitiivi 81,56 partitiivi 58,80 - ainsuse partitiivi 45,81 - translatiiviga $26,46 \mathrm{jt}$, sarnasused aga ainsuse genitiivi o,16 - allatiivi 1,54 - komitatiivi 2,36 - elatiivi 2,57 - mitmuse elatiivi 2,84 - illatiivi 4,43 ja ainsuse terminatiiviga 4,43 (vt tabel 8).

Tabel 8. Sõna aeg käändekasutuse sarnasus/erinevus EKI tekstikorpuses ja EVKK-s

\begin{tabular}{|c|c|c|c|c|c|}
\hline \multirow{2}{*}{ Kääne } & \multicolumn{2}{|c|}{ EKI tekstikorpus } & \multicolumn{2}{|c|}{ EVKK } & \multirow[b]{2}{*}{$x^{2}$} \\
\hline & $\mathbf{a}$ & b & C & d & \\
\hline SG.NOM & 1168 & 3518 & 567 & 2888 & 85,96 \\
\hline PL.NOM & 184 & 4502 & 0 & 3455 & 138,78 \\
\hline SG.GEN & 310 & 4376 & 221 & 3234 & 0,16 \\
\hline PL.GEN & 184 & 4502 & 25 & 3430 & 81,56 \\
\hline SG.PART & 1268 & 3418 & 710 & 2745 & 45,81 \\
\hline PL.PART & 114 & 4572 & 11 & 3444 & 58,80 \\
\hline SG.ILL & 0 & 4686 & 0 & 3455 & - \\
\hline PL.ILL & 6 & 4680 & 0 & 3455 & 4,43 \\
\hline SG.INES & 41 & 4645 & 64 & 3391 & 14,92 \\
\hline PL.INES & 0 & 4686 & 0 & 3455 & - \\
\hline SG.ELAT & 109 & 4577 & 100 & 3355 & 2,57 \\
\hline PL.ELAT & 27 & 4659 & 11 & 3444 & 2,84 \\
\hline SG.ALL & 16 & 4670 & 18 & 3437 & 1,54 \\
\hline PL.ALL & 0 & 4686 & 0 & 3455 & - \\
\hline SG.ADS & 1020 & 3666 & 1583 & 1872 & 528,81 \\
\hline PL.ADS & 43 & 4643 & 16 & 3439 & 5,71 \\
\hline SG.ABL & 0 & 4686 & 60 & 3395 & 81,97 \\
\hline PL.ABL & 0 & 4686 & 0 & 3455 & - \\
\hline SG.TRANS & 144 & 4542 & 46 & 3409 & 26,46 \\
\hline PL.TRANS & 0 & 4686 & 0 & 3455 & - \\
\hline SG.TERM & 6 & 4680 & 0 & 3455 & 4,43 \\
\hline PL.TERM & 0 & 4686 & 0 & 3455 & - \\
\hline SG.ESS & 0 & 4686 & 0 & 3455 & - \\
\hline PL.ESS & 0 & 4686 & 0 & 3455 & - \\
\hline SG.ABES & 0 & 4686 & 0 & 3455 & - \\
\hline PL.ABES & 0 & 4686 & 0 & 3455 & - \\
\hline SG.KOM & 46 & 4640 & 23 & 3432 & 2,36 \\
\hline PL.KOM & 0 & 4686 & 0 & 3455 & - \\
\hline Kokku & 4686 & & 3455 & & \\
\hline
\end{tabular}

Sõna aeg käändevormide sagedusandmed kirjakeeles ja õppijakeeles näitavad kahe keelevariandi vahelist sünkroonsust (vt joonis 3). See väljendub ühelt poolt üksikute käändevormide kõrges sageduses ja teisalt paljude käändevormide samalaadses mittekasutamises, mis tuleneb sõna semantikast (vt tabel 9). 


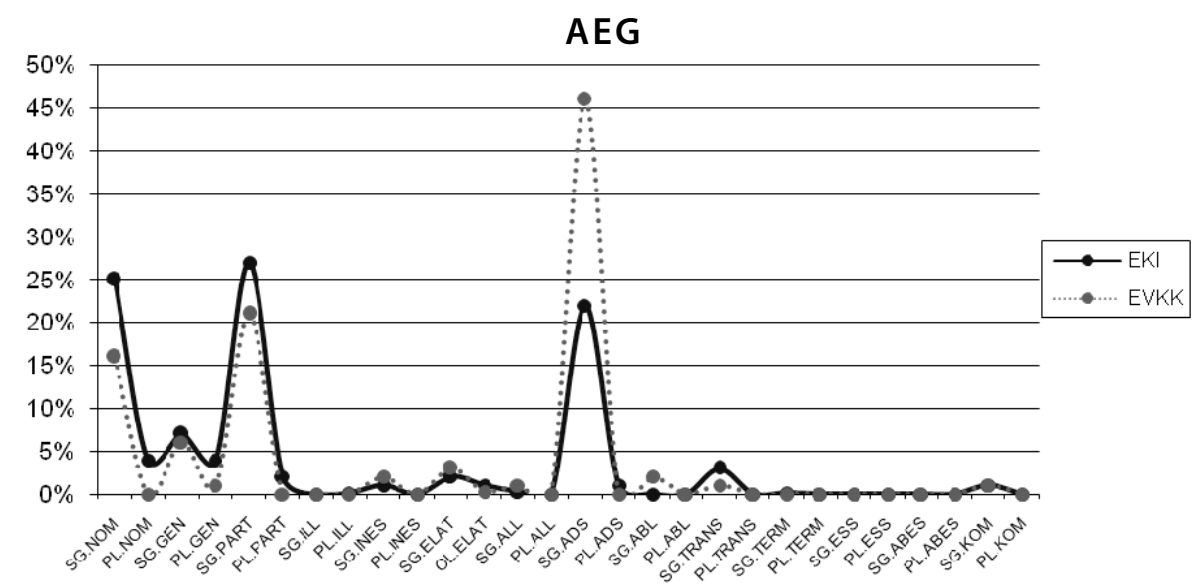

Joonis 3. Sõna aeg käändevormide sagedus EKI tekstikorpuses ja EVKK-s

Tabel 9. Erinevused sõna aeg käändevormide sageduses

\begin{tabular}{|l|r|r|r|r|c|}
\hline Käänded & EKI & Sagedus & EVKK & Sagedus & Erinevus \\
\hline SG.NOM & $25 \%$ & 1168 & $16 \%$ & 567 & $9 \%$ \\
\hline PL.NOM & $4 \%$ & 184 & $0 \%$ & 0 & $4 \%$ \\
\hline SG.GEN & $7 \%$ & 310 & $6 \%$ & 221 & $1 \%$ \\
\hline PL.GEN & $4 \%$ & 184 & $1 \%$ & 25 & $3 \%$ \\
\hline SG.PART & $27 \%$ & 1268 & $21 \%$ & 710 & $6 \%$ \\
\hline PL.PART & $2 \%$ & 114 & $0 \%$ & 11 & $2 \%$ \\
\hline SG.ILL & $0 \%$ & 0 & $0 \%$ & 0 & $0 \%$ \\
\hline PL.ILL & $0,1 \%$ & 6 & $0 \%$ & 0 & $0 \%$ \\
\hline SG.INES & $1 \%$ & 41 & $2 \%$ & 64 & $1 \%$ \\
\hline PL.INES & $0 \%$ & 0 & $0 \%$ & 0 & $0 \%$ \\
\hline SG.ELAT & $2 \%$ & 109 & $3 \%$ & 100 & $1 \%$ \\
\hline PL.ELAT & $1 \%$ & 27 & $0,3 \%$ & 11 & $1 \%$ \\
\hline SG.ALL & $0,3 \%$ & 16 & $1 \%$ & 18 & $1 \%$ \\
\hline PL.ALL & $0 \%$ & 0 & $0 \%$ & 0 & $0 \%$ \\
\hline SG.ADS & $22 \%$ & 1020 & $46 \%$ & 1583 & $24 \%$ \\
\hline PL.ADS & $1 \%$ & 43 & $0 \%$ & 16 & $1 \%$ \\
\hline SG.ABL & $0 \%$ & 0 & $2 \%$ & 60 & $2 \%$ \\
\hline PL.ABL & $0 \%$ & 0 & $0 \%$ & 0 & $0 \%$ \\
\hline SG.TRANS & $3 \%$ & 144 & $1 \%$ & 46 & $2 \%$ \\
\hline PL.TRANS & $0 \%$ & 0 & $0 \%$ & 0 & $0 \%$ \\
\hline SG.TERM & $0,1 \%$ & 6 & $0 \%$ & 0 & $0 \%$ \\
\hline PL.TERM & $0 \%$ & 0 & $0 \%$ & 0 & $0 \%$ \\
\hline SG.ESS & $0 \%$ & 0 & $0 \%$ & 0 & $0 \%$ \\
\hline PL.ESS & $0 \%$ & 0 & $0 \%$ & 0 & $0 \%$ \\
\hline SG.ABES & $0 \%$ & 0 & $0 \%$ & 0 & $0 \%$ \\
\hline PL.ABES & $0 \%$ & 0 & $0 \%$ & 0 & $0 \%$ \\
\hline SG.KOM & $1 \%$ & 46 & $1 \%$ & 23 & $0 \%$ \\
\hline PL.KOM & $0 \%$ & 0 & $0 \%$ & 0 & $0 \%$ \\
\hline
\end{tabular}


Kasutatud ei ole järgmisi käändevorme: ainsuse illatiiv; mitmuse inessiiv, allatiiv, ablatiiv, translatiiv, terminatiiv; ainsuse ja mitmuse essiiv ning abessiiv; mitmuse komitatiiv. Õppijakeele korpuses puudusid ka mitmuse illatiiv ja ainsuse terminatiiv; kirjakeeleski oli nende vormide sagedus vaid o,01\%. Samuti polnud õppijakeeles esindatud mitmuse nominatiiv, mis kirjakeeles moodustas sõna aeg käändevormidest 4\%. Kõige sagedamini esines nii EKI tekstikorpuse kui ka EVKK valimites kolm käänet: ainsuse nominatiiv (vastavalt $25 \%$ ja $16 \%$ ), partitiiv ( $27 \%$ ja 21\%) ja adessiiv (22\% ja 46\%). Tunduvalt harvemini oli kasutatud ainsuse genitiivi (vastavalt 7\% ja 6\%). Võrreldes kirjakeelega oli õppijakeeles selgelt ülekasutatud käändevorm ainsuse adessiiv (erinevus 24\%), alakasutatud aga ainsuse nominatiiv (erinevus on 9\%) ja partitiiv (erinevus 6\%), vähemal määral mitmuse nominatiiv (erinevus $4 \%$ ) ja genitiiv (erinevus $3 \%$ ).

\subsection{Sõna sõna käändevormide statistika}

Sõna sõna käändevormide kasutuses on EKI tekstikorpuse ja EVKK vahelised lahknevused seotud nii grammatiliste kui ka semantiliste käänetega (vt tabel 10): mitmuse elatiiv 37,45 - ainsuse genitiiv 32,20 - mitmuse nominatiiv 27,31 - ainsuse nominatiiv 25,43 - ainsuse allatiiv 21,80 - mitmuse komitatiiv 20,81 - mitmuse partitiiv 20,03 - mitmuse adessiiv 17,91 - ainsuse komitatiiv 17,55 - ainsuse partitiiv 16,90 - ainsuse ablatiiv 12,23 - mitmuse inessiiv 12,05. Sarnaselt oli kasutud semantilisi käändeid: mitmuse translatiivi 2,54 ja genitiivi 2,67 - ainsuse inessiivi 2,90, adessiivi 3,17 ja elatiivi 3,18 - mitmuse ablatiivi 4,oo ja allatiivi 4,38.

Tabel 10. Sõna sõna käändekasutuse sarnasus/erinevus EKI tekstikorpuses ja EVKK-s

\begin{tabular}{|c|c|c|c|c|c|}
\hline \multirow{2}{*}{ Käänded } & \multicolumn{2}{|c|}{ EKI tekstikorpus } & \multicolumn{2}{|c|}{ EVKK } & \multirow{2}{*}{$x^{2}$} \\
\hline & $\mathbf{a}$ & b & c & d & \\
\hline SG.NOM & 397 & 2212 & 82 & 863 & 25,43 \\
\hline PL.NOM & 353 & 2256 & 196 & 749 & 27,61 \\
\hline SG.GEN & 233 & 2376 & 31 & 914 & 32,20 \\
\hline PL.GEN & 293 & 2316 & 88 & 857 & 2,67 \\
\hline SG.PART & 248 & 2361 & 49 & 896 & 16,90 \\
\hline PL.PART & 72 & 2537 & 56 & 889 & 20,03 \\
\hline SG.ILL & 0 & 2609 & 0 & 945 & - \\
\hline PL.ILL & 19 & 2590 & 0 & 945 & 6,92 \\
\hline SG.INES & 8 & 2601 & 0 & 945 & 2,90 \\
\hline PL.INES & 78 & 2531 & 9 & 936 & 12,05 \\
\hline SG.ELAT & 49 & 2560 & 27 & 918 & 3,18 \\
\hline PL.ELAT & 51 & 2558 & 56 & 889 & 37,45 \\
\hline SG.ALL & 24 & 2585 & 29 & 916 & 21,80 \\
\hline PL.ALL & 40 & 2569 & 6 & 939 & 4,38 \\
\hline SG.ADS & 38 & 2571 & 22 & 923 & 3,17 \\
\hline PL.ADS & 342 & 2267 & 75 & 870 & 17,91 \\
\hline SG.ABL & 13 & 2596 & 16 & 929 & 12,23 \\
\hline PL.ABL & 11 & 2598 & 0 & 945 & 4,00 \\
\hline SG.TRANS & 0 & 2609 & 0 & 945 & - \\
\hline PL.TRANS & 7 & 2602 & 0 & 945 & 2,54 \\
\hline
\end{tabular}




\begin{tabular}{|l|c|c|c|c|c|}
\hline \multirow{2}{*}{ Käänded } & \multicolumn{2}{|c|}{ EKI tekstikorpus } & \multicolumn{2}{c|}{ EVKK } & \multirow{2}{*}{$\mathbf{X}^{\mathbf{2}}$} \\
\cline { 2 - 5 } & $\mathbf{a}$ & $\mathbf{b}$ & $\mathbf{c}$ & $\mathbf{d}$ & - \\
\hline SG.TERM & 0 & 2609 & 0 & 945 & - \\
\hline PL.TERM & 0 & 2609 & 0 & 945 & - \\
\hline SG.ESS & 0 & 2609 & 0 & 945 & - \\
\hline PL.ESS & 0 & 2609 & 0 & 945 & - \\
\hline SG.ABES & 0 & 2609 & 0 & 945 & - \\
\hline PL.ABES & 0 & 2609 & 0 & 945 & 17,55 \\
\hline SG.KOM & 116 & 2493 & 76 & 869 & 20,81 \\
\hline PL.KOM & 217 & 2392 & 127 & 818 & \\
\hline Kokku & $\mathbf{2 6 0 9}$ & & $\mathbf{9 4 5}$ & & \\
\hline
\end{tabular}

Nii EKI tekstikorpuses kui ka EVKK-s polnud üldse tarvitatud kolme käändevormi: ainsuse illatiivi, translatiivi ja terminatiivi (vt tabel 11). Lisaks puudusid õppijakeeles ka mitmuse illatiivi, ainsuse inessiivi, mitmuse ablatiivi ja translatiivi vormid, mida kirjakeeles küll leidus, kuid niivõrd harva, et väike erinevus $1 \%$ ilmnes vaid mitmuse illatiivi sageduses. Kirjakeele sagedasem kääne sõnaga sõna oli nominatiiv: ainsuse $15 \%$ ja mitmuse nominatiiv $14 \%$. Järgnesid mitmuse adessiiv $13 \%$ ja genitiiv $11 \%$, ainsuse partitiiv $10 \%$ ja genitiiv $9 \%$, mitmuse $8 \%$ ja ainsuse komitatiiv $4 \%$, mitmuse partitiiv $3 \%$ ja inessiiv $3 \%$, ainsuse elatiiv $2 \%$, mitmuse allatiiv $2 \%$.

Tabel 11. Erinevused sõna sõna käändevormide sageduses

\begin{tabular}{|l|c|r|r|r|c|}
\hline Käänded & EKI tekstikorpus & Sagedus & EVKK & Sagedus & Erinevus \\
\hline SG.NOM & $15 \%$ & 397 & $9 \%$ & 82 & $6 \%$ \\
\hline PL.NOM & $14 \%$ & 353 & $21 \%$ & 196 & $7 \%$ \\
\hline SG.GEN & $9 \%$ & 233 & $3 \%$ & 31 & $6 \%$ \\
\hline PL.GEN & $11 \%$ & 293 & $9 \%$ & 88 & $2 \%$ \\
\hline SG.PART & $10 \%$ & 248 & $5 \%$ & 49 & $5 \%$ \\
\hline PL.PART & $3 \%$ & 72 & $6 \%$ & 56 & $3 \%$ \\
\hline SG.ILL & $0 \%$ & 0 & $0 \%$ & 0 & $0 \%$ \\
\hline PL.ILL & $1 \%$ & 19 & $0 \%$ & 0 & $1 \%$ \\
\hline SG.INES & $0,3 \%$ & 8 & $0 \%$ & 0 & $0 \%$ \\
\hline PL.INES & $3 \%$ & 78 & $1 \%$ & 9 & $2 \%$ \\
\hline SG.ELAT & $2 \%$ & 49 & $3 \%$ & 27 & $1 \%$ \\
\hline PL.ELAT & $2 \%$ & 51 & $6 \%$ & 56 & $4 \%$ \\
\hline SG.ALL & $1 \%$ & 24 & $3 \%$ & 29 & $2 \%$ \\
\hline PL.ALL & $2 \%$ & 40 & $1 \%$ & 6 & $1 \%$ \\
\hline SG.ADS & $1 \%$ & 38 & $2 \%$ & 22 & $1 \%$ \\
\hline PL.ADS & $13 \%$ & 342 & $8 \%$ & 75 & $5 \%$ \\
\hline SG.ABL & $0,5 \%$ & 13 & $2 \%$ & 16 & $2 \%$ \\
\hline PL.ABL & $0,4 \%$ & 11 & $0 \%$ & 0 & $0 \%$ \\
\hline SG.TRANS & $0,3 \%$ & 0 & $0 \%$ & 0 & $0 \%$ \\
\hline PL.TRANS & $0 \%$ & 7 & $0 \%$ & 0 & $0 \%$ \\
\hline SG.TERM & 416 & $0 \%$ & 0 & $0 \%$ \\
\hline SG.KOM & $0 \%$ & $13 \%$ & 127 & $4 \%$ \\
\hline PL.KOM & 17 & & & $5 \%$ \\
\hline
\end{tabular}


Võrreldes kirjakeelega oli õppijakeeles kõige rohkem ülekasutatud mitmuse nominatiivi - 21\%; erinevus EKI tekstikorpuse vormisagedusest on 7\%. Ülekasutatud oli ka mitmuse (erinevus $5 \%$ ) ja ainsuse komitatiivi (erinevus 4\%). Alakasutatud käändevormid olid: ainsuse nominatiiv ja genitiiv (mõlemal juhul erinevus 6\%), ainsuse partitiiv ja mitmuse adessiiv (erinevus $5 \%$ ).

Kui võrrelda sõna käändevormide sageduserinevusi kirjakeeles ja õppijakeeles, siis hakkab silma, et märgatavamad vormisageduse kõikumised on seotud grammatiliste käänetega, eriti mitmuse nominatiivi, ainsuse nominatiivi ja genitiiviga, samuti ainsuse partitiivi, mitmuse elatiivi, adessiivi ja ainsuse ning mitmuse komitatiiviga (vt joonis 4).

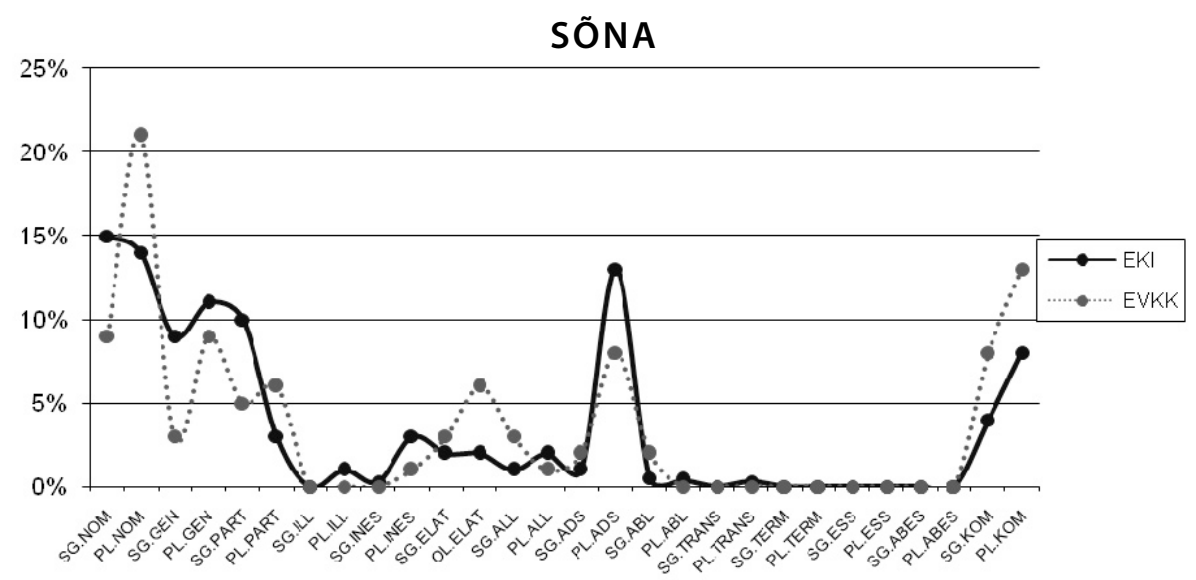

Joonis 4. Sõna sõna käändevormide sagedus EKI tekstikorpuses ja EVKK-s

\subsection{Kokkuvõtvalt käändevormide statistikast}

Võrrelnud nelja sagedasema nimisõna (inimene, elu, aeg, sõna) käändevormide sagedust, võib väita järgmist.

- Üheselt ei saa öelda, et eesti keele nimisõnade käändeparadigma iseloomulikuks jooneks on grammatiliste ja semantiliste käänete vastandatus, sest käändevormide esinemine või mitteesinemine sõltub sõna semantikast, seoste loogikast semantika ja grammatika vahel (vt elu, aeg, sõna käändevormide sagedus paradigmas).

- Eesti kirjakeele ja õppijakeele käändevormide sageduse võrdlus näitab nende kahe keelevariandi käändeparadigmade samalaadsust ja sünkroonsust, mis ei tulene sellest, et õppijad on nimisõnade käändeparadigma hästi omandanud; tendentsi põhjus peitub keele sisemises loogikas, grammatiliste vormide moodustamises olenevalt sõna semantikast.

- Võrdlusest kirjakeelega ilmneb, et õppijakeeles on suundumus ülekasutada nominatiivi (inimene - ainsuses ja mitmuse vormis, sõna - mitmuses, elu ainsuses), kuid samas on ka kirjakeeles sel käändel kõrged sagedusnäitajad (sõna - ainsuse ja mitmuse nominatiiv on käändevormide sagedusreas esikohal, inimene - mitmuse nominatiiv on ainsuse partitiivi järel sageduselt teine vorm ja ainsuse nominatiiv - kolmas, aeg - ainsuse nominatiiv on 
ainsuse partitiivi järel sageduselt teisel kohal, elu - ainsuse nominatiiv on ainsuse inessiivi ja elatiivi järel käänete sagedusrea kolmas vorm); järelikult ei saa nominatiivi suurt sagedust pidada üheselt õppijakeele spetsiifiliseks jooneks, sest ka kirjakeeles on nominatiiv sage kääne ning ainsuse partitiiv on vaid kahe sõna puhul (inimene, aeg) kerges ülekaalus; seetõttu ei saa analüüsitud keeleainese alusel väita, et eesti keele käändesüsteemis kehtib partitiivi ja nominatiivi vastandus, mille markeerimata liige on partitiiv.

- Õppijakeeles on üle kasutatud mitmuse (inimene) ning ainsuse ja mitmuse komitatiivi (sõna); jällegi pole tegu õppijakeele spetsiifikaga, sest ka kirjakeeles on komitatiivi sagedus ülejäänud semantiliste käänete sagedusest kõrgem (inimene - mitmuse vormis, elu - ainsuses ja sõna - ainsuses ja mitmuses), järelikult on tegu samalaadse nähtusega, mis erinevates keelevariantides ilmneb erineva sagedusega.

- Õppijakeeles on üle kasutatud ainsuse inessiivi (elu) ja adessiivi (aeg), kuid ka kirjakeeles on sõna elu sagedasem vorm inessiiv ning sõna aeg adessiivi vormi kasutatakse ainsuse partitiivi ja nominatiivi järel kolmandana; tegu on samalaadse nähtusega.

- Õppijakeeles on alakasutatud ainsuse genitiivi ja partitiivi (inimene, aeg), ainsuse nominatiivi ja partitiivi (sõna), ainsuse nominatiivi (aeg), ainsuse elatiivi ja allatiivi, mitmuse terminatiivi ja komitatiivi (elu), mitmuse adessiivi (sõna), kuid ka selles osas on märgata sünkroonsust kirjakeelega, kus neid käändeid on teistega võrreldes vähem kasutatud.

Küsimused tekivad siis, kui õppijakeele käändevormide üle- ja alakasutus hakkab regulaarselt koonduma samade vormide ümber ning kaob vormisageduse sünkroonsus loomuliku keelekasutusega. Sel juhul võib olla tegu õppijakeelele omase ebatüüpilise vormikasutusega, mille põhjusi tasuks uurida. Lisaks õppija mitteaktsepteeritavale vormikasutusele võib osutuda ka võimalikuks, et õppijakeel kajastab loomulikus keeles varjatult kulgevaid keelemuutusi. Kadri Sõrmuse arvamuse järgi on keeleõppija vastuvõtlik kõigele, mida ta erinevates suhtlussituatsioonides kogeb, eriti sellele, mida pakuvad erinevad meediakanalid ja tavasuhtlus (Sõrmus 2008: 35). Et nendele protsessidele jälile saada, ei piisa nelja sagedasema nimisõna käändevormide statistikast - vaja oleks läbi viia tunduvalt avaramapõhjaline uurimus, mis tugineks kahe keeleainese võtmesõnaanalüüsile (KeyWords analysis), vt eespool punkt 2.3. Teisalt ei saa statistilisi erinevusi ehk käändevormide üle- ja alakasutust õppijakeeles siduda automaatselt ebatüüpilise vormikasutusega. Selleks on vaja võrrelda kirjakeele ja õppijakeele tekstiloomes eelistatud konstruktsioone, milles ilmnevad ainult teatud kindlad sõnad ja käändevormid.

\section{Tekstiloomes eelistatud konstruktsioonid ja käändevormid}

\subsection{Sõna inimene}

Kuna selle sõna eri käändevormidel on rohkesti kasutusmustreid, siis kirjeldatakse konstruktsioone ja nende leksikaalseid ning grammatilisi variante käänete kaupa. 


\subsubsection{Ainsuse nominatiiv - inimene}

EKI tekstikorpuses on eelistatud kasutada substantiivset konstruktsiooni inimene ja seadus inimene ja loodus, loogilist implikatsiooni kui inimene on et inimene on ja eitust inimene ei ole (ei saa). EVKK-s on eelistatud nii loogilist implikatsiooni kui inimene on (variandid: kui inimene tahab, kogeb, elab, suhtleb) et inimene peab ja kui (et kui, sest kui) inimene kui ka modaalseid lausekonstruktsioone inimene peab olema (maksma, teadma) inimene võib töötada; haritud (iga) inimene peab (saab, võib, tahab) ja eitust inimene ei saa (ei ole).

Normkirjakeele seisukohalt on kõik need konstruktsioonid tavapärased - analüüsitavates keelevariantides on lihtsalt erinevad kasutuseelistused. Sama kehtib konstruktsioonide leksikaalgrammatilise varieeruvuse kohta. Õppijakeele konstruktsioonidel on tänu modaal-, olemis- ja kogemisverbide vaheldumisele päris palju leksikaalseid variante (verbid tahtma, teadma, võima, saama, olema, elama, kogema, suhtlema, maksma indikatiivi ainsuse 3. pöördes); konstruktsioonid varieeruvad ka grammatiliselt (sidendid kui, et, ja kui, et kui, sest kui ning jaatav / eitav kõneliik). Kirjakeelse substantiivkonstruktsiooni leksikaalne varieeruvus piirdub kahe võimalusega: inimene ja seadus inimene ja loodus. Samas lubab keelenorm selle konstruktsiooniga vabalt kasutada muidki abstraktseid sõnu (nt inimene ja kosmos, inimene ja ühiskond, inimene ja meri, inimene ja elu, inimene ja aeg jne). Niisugused substantiivkonstruktsioonid on tavapärased teema sõnastamisel ja sobivad pealkirjaks. EKI tekstikorpuse analüüs näitas, et võimalikest teemasõnadest esines kolm: inimene, seadus ja loodus. Need märksõnad toovad esile praegusaja Eesti riigi ning ühiskonna ühe olulisema sotsiaalpoliitilise diskursuse, mida kajastavad EKI tekstikorpuse ajakirjandustekstid. Teisena esile tulnud verbikesksete konstruktsioonidega oli väljendatud tingimust või millegi lubatavust. EVKK-s on sõna inimene käändevormide kasutamisel eelistatud modaalset, tingimuslik-eksistentsiaalset ja põhjendavat diskursust. Erinevus valikutes tuleneb kirjakeele ja õppijakeele diskursuste spetsiifikast: esimeses on rõhutatud inimesega seotud aktuaalset teemat ja viidatud sellele, mida inimene ei saa ega tohi teha; teises tuginetakse abstraktsele arutelule inimese olemise, vajaduste ja võimaluste üle, püüdes neid põhjendada.

\subsubsection{Mitmuse nominativ - inimesed}

Mitmuse nominatiivi vormiga on kirjakeeles eelistatud kolme konstruktsiooni ja nende variante: 1) need inimesed kes (kellele), 2) et inimesed on (ei ole) et (ka) need inimesed ja 3) need inimesed on. Õppijakeeles on kasutatud analoogseid konstruktsioone - erineb vaid konstruktsiooni kordumise sagedus ja leksikaalgrammatiline varieeruvus: 1) kõik (need) inimesed on (hoidsid, tahavad) ja 2) inimesed kes on (ei ole). EVKK-s sisalduvate tekstide spetsiifikast johtub konstruktsiooni noorkeraamika (kammkeraamika) inimesed sarnanesid esile kerkimine, kuna korpuses on palju Eesti kultuuriloo teemalisi esseid ja kontrolltöid. 


\subsubsection{Ainsuse genitiiv - inimese}

EKI tekstikorpuses on ainsuse genitiivi kasutatud valdavalt kvantorfraasis: üle 200 (500o, 30o, tuhande, saja) inimese. Konstruktsiooniga antakse hinnang meie elu negatiivsetele nähtustele: katastroofid, kollapsid, liiklusõnnetused jms, kus on surma saanud/hukkunud sadu ja tuhandeid inimesi. Õppijakeele tekstides pole see teema olnud aktuaalne. Esile kerkivad hoopiski arutlused selle üle, mis mõjutab / ei mõjuta inimese elu või mis on elus tähtis: mõjutab (ei mõjuta) inimese elu inimese elu mõjutab. Selles lausekonstruktsioonis varieeruvad sõnajärg ja kõneliik, verbi on kasutatud indikatiivi oleviku 3. pöördes. Sama sagedusega oli kasutatud ka inimese elu kirjeldavat noomenikonstruktsiooni, mille mittegrammatilised sõnavormid võivad tekitada arusaamisraskusi: inimese elu kõige $\sim$ ?inimese elu haridus $\sim$ *inimese elu tema (?teema) *inimese elu ma (?maal).

\subsubsection{Mitmuse genitiiv - inimeste}

Konstruktsioone, milles peaks olema kasutud mitmuse genitiivi, eesti kirjakeeles ei olnud. Õppijakeeles esines verbikonstruktsioon kahjustab inimeste tervist. Selle leksikaalne variant matkida inimeste magamisasendit on spetsiifiline, st iseloomulik kultuuriloo kursuse kontrolltöödele (vt PL.NOM).

\subsubsection{Ainsuse partitiiv - inimest}

EKI tekstikorpuse materjalides on seda käändevormi kasutatud kvantorfraasis, kus varieeruvad määr- ja arvsõnad: ligi (veel, umbes) 200 ( kolm, 80o) inimest; hukkus kolm (kaheksa, kuus, viis, üksteist) inimest. Ka see konstruktsioon iseloomustab sotsiaalset diskursust: rõhutatult on esile toodud katastroofides ja õnnetustes hukkunute arv. EVKK-s on samuti eelistatud kvantorfraasi: ainult (umbes) kuus (sada) inimest; ning kaheksa (üksteist) inimest, kaheksa (kuus) inimest 32-st, kuid õppijakeeles ei räägita hukkunute arvust - tavapäraselt on kvantorfraasi kasutatud verbi kirjutama imperfekti mitmuse 3. pöördega (üksteist inimest kirjutasid).

\subsubsection{Mitmuse partitiiv - inimesi}

Kirjakeeles on seda vormi kasutatud konstruktsioonides 1) inimesi kellel on inimesi kes ei; 2) neid inimesi kes ja 3) on inimesi kes, samas kui õppijakeele eelistus on rõhusõna sisaldav kvantorfraas väga (nii) palju inimesi. See näide toob esile täiesti erinevad valikud: kirjakeeles on eelistatud öelda, missuguseid inimesi üldse on, õppijakeeles rõhutatakse inimeste hulka, mis midagi teeb. Kvantorigaväga (nii) palju toonitatakse kõnealuse nähtuse positiivsust. 


\subsubsection{Ainsuse adessiiv - inimesel}

Sõna inimene ainsuse adessiivi vormi kasutamine on õppijakeelekeskne (nagu ka ainsuse nominatiivi eelistamine modaalsetes konstruktsioonides ja loogilistes implikatsioonides). Konstruktsiooni kui inimesel on (ei ole) on kasutatud jaatavas ja eitavas kõneliigis; sage on olnud ka modaalne konstruktsioon igal inimesel on (peab olema). Oma tekstides on õppijad kirjutanud kohustustest, mis inimesel on / peavad olema, samas kui EKI tekstikorpuse materjalides pole see teema esile tõusnud.

\subsection{Sõna elu}

Sõna elu käändevormide kasutus on selgepiiriline: kirjakeeles on eelistatud konstruktsioone ainsuse nominatiiviga ja ôppijakeeles ainsuse inessiivi, nominatiivi, genitiivi ja partitiiviga. EKI tekstikorpuses on kõige enam kasutatud substantiivkonstruktsiooni haridus ja elu kultuur ja elu ja lausekonstruktsiooni tema (ta) elu on, milles sõna elu on ainsuse nominatiivis. Esile on toodud meie elu iseloomustav ja oluline teema - haridus, elu ja kultuur. Vastupidiselt kirjakeelele on EVKK-s kirjutatud peamiselt iseendast ja oma elust, sellest, mis minu ja teiste inimeste elus on, oli või olema peab. Sel eesmärgil on õppijakeeles eelistatud hulgaliselt konstruktsioone ja nende leksikaalgrammatilisi variante, milles sõna elu saab kasutada 1) ainsuse inessiivi vormis - minu elus on (oli) meie elus on; elus on palju (väga); 2) ainsuse nominatiivis ning koos verbidega olema, võima, sõltuma ja erinema oleviku ainsuse 3. pöördes - inimese elu on (võib, sõltub, erineb); elu sõltub elukohast, <meie> elu erineb Ukraina <elust>; elu on väga; 3) ainsuse genitiivi vormis lausekonstruktsioonis ja vanemate elu et noorte elu et inimese elu; 4) ainsuse partitiivis ja koos verbiga mõjutama ainsuse/mitmuse oleviku 3. pöördes - inimese elu mõjutab mõjutavad inimese elu. Hakkab silma, et õppijakeeles on eelistatud konstruktsioone, milles saab kasutada nii semantiliste kui ka grammatiliste käänete vorme, kirjakeeles seevastu on eelistatud vaid ainsuse nominatiivi.

\subsection{Sõna aeg}

Sõna $a e g$ on nii kirjakeeles kui ka õppijakeeles kasutatud suure hulga konstruktsioonide ja nende leksikaalgrammatiliste variantidega.

\subsubsection{Ainsuse nominatiiv - aeg}

EKI tekstikorpuses on kõige rohkem korduv konstruktsioon <on (käes)> teoinimeste aeg, mida võib pidada kirjakeelse esituslaadi stereotüübiks. Ka õppijakeeles on eelistatud samalaadseid konstruktsioone: 1) see aeg on mõni aeg oli; 2) muutub (on) kogu aeg; 3) on aeg kus; 4) lendab aeg väga. Peale selle on kirjakeeles tavapärased konstruktsioonid, mille abil saab hinnata indiviide, predikaate või ajahetke ning sel viisil kaudselt üleskutset väljendada: 1) lausekonstruktsioon on ilus (paras, viimane, õige) aeg; 2) kvantorfraasid mõni aeg hiljem mõni aeg pärast <mida> ja on (oli, olnud, ajanud) kogu aeg; 3) lausekonstruktsioonid aeg on kallis $\sim$ aeg on möödas (läbi, käes) ja et viimane aeg <on mida teha> oli aeg mil. 


\subsubsection{Ainsuse genitiiv - aja}

Kirjakeele kasutusmallide hulgas näited puuduvad; õppijakeeles oli üks konstruktsioon: <mõne> aja pärast tuli (oli).

\subsubsection{Mitmuse genitiiv - aegade}

Tavapäraseid konstruktsioone, milles peaks kasutama mitmuse genitiivi, kirjakeeles ei esinenud. Õppijakeele analüüsis tuli välja viis korduvat konstruktsiooni: 1) kõigi aegade suurim (parim, esimene, teine); 2) on läbi aegade läbi aegade on; 3) on kõigi aegade; 4) ESTO-d läbi aegade ja 5) Eesti kõigi aegade. Kõiki neist konstruktsioonidest on võimalik kasutada positiivse hinnangu andmiseks, eriti kui jutt on saavutustest spordis, kultuuris, majanduses jne. Eesti kirjakeele kasutajale pole see teemaring olnud samavõrd oluline.

\subsubsection{Ainsuse partitiiv - aega}

Selle käändevormiga on nii EKI tekstikorpuses kui ka EVKK-s rikkalik kogum konstruktsioone. Kirjakeele sagedasim oli ajatähenduslik kvantorfraas kuu aega tagasi (hiljem, enne). Järgnesid ligilähedast või pikka ajavahemikku tähistavad kvantorfraasid umbes (ligi,ja) kuu aega; juba pikka aega väga pikka aega; oli (on) pikka aega pikka aega on; tükk aega tagasi (pärast); nädal aega tagasi; on veel aega $\sim$ vajan veidi aega. Nende kvantorfraasidega hinnatakse indiviide, predikaate või ajahetki.

EVKK-le on iseloomulik kasutada konstruktsiooni vabadus (vajadus, *vabanduse) planeerida aega, mis tänu kõrgele sagedusele on õppijakeele stereotüüpne konstruktsioon hinnangulisuse edastamisel. Väga sageli kordus ka modaalne kvantorfraas *pidis ( ${ }^{*}$ pidab, pidada, pidama) mõnda aega. Selle konstruktsiooni mittegrammatilised pöördevormid viitavad õppija jaoks ühele suuremale vormimoodustusraskusele: *pidis pidi, *pidab peab. Sageli on kvantorfraasi kasutatud selleks, et rõhutada, kas aega napib või on liialt palju: väga vähe aega nii palju aega liiga palju aega. Sageli korduv on olnud ka eitust sisaldav konstruktsioon ei ole (ei olnud) aega.

\subsubsection{Ainsuse adessiiv - ajal}

Selle vormiga moodustatud konstruktsioonid ja nende leksikaalgrammatilised variandid on õppijakeele spetsiifiline nähtus. Kõige sagedamini tuli ainsuse adessiiv esile 1) modaalses konstruktsioonis külmal ajal peab; 2) lausekonstruktsioonides et (kuid, sest) sel ajal sest tol ajal ja samal ajal ja tol (sellel) ajal tekkis (kasutati) $\sim$ samal ajal läksid praegusel (sel, sellel) ajal on vabariigi (vene, * ${ }^{*}$ tsari) ajal oli sõja ajal polnud vabal (vabariigi) ajal teha; 3) noomenikonstruktsioonis samal ajal ajaloolised $<$ sündmused $>\sim$ tol ajal inimesed $\sim$ sel ajal laulud. 


\subsection{Sõna sõna}

Nii kirjakeeles kui ka õppijakeeles on sõna käändevormidel spetsiifilised kasutusmustrid. Neid ei ole palju ja seetõttu puudub vajadus esitada kirjeldus käänete kaupa. Näiteks EKI tekstikorpuse alusel tulid esile järgmised kirjakeele stereotüüpsed konstruktsioonid: 1) noomenikonstruktsioon ainsuse genitiiviga (sõna otseses mõttes (tähenduses) ja selle leksikaalsed variandid selle sõna otseses (kõige $<$ otsesemas mõttes, tähenduses >); 2) noomenikonstruktsioon ja selle leksikaalsed variandid mitmuse genitiiviga (tema (oma) sõnade kohaselt (järgi, eest)). Vähem kordusid hinnangulisust edastavad stereotüüpsed konstruktsioonid, kus oli kasutatud ainsuse nominatiivi ja genitiivi: tehnika vïmane sõna oma vïmase sõna ja oma sõna öelda (ütlema).

Õppijakeele spetsiifika selle sõna kasutuses tuleneb korduvatest tööjuhistest, mis EVKK-s pole tekstidest eraldatud: nt ainsuse ja mitmuse nominatiiv - pane sõna (d) õigesse <vormi>, ainsuse partitiiv - umbes $80(120,160)$ sõna, mitmuse komitatiiv - moodustage etteantud sõnadega. Ülejäänud juhtudel on ainsuse nominatiivi vormi kasutatud noomenikonstruktsioonides (sõna eesti kultuur, väga levinud sõna nö esimene sõna) ja lausekonstruktsioonis esimene sõna mis. Ka mitmuse genitiivi on EVKK-s kasutatud noomenikonstruktsioonides hümni sõnade kirjutaja (autor), Eesti hümni sõnade ja lausekonstruktsioonides et hümni sõnade; sõnade autor oli. Ainsuse partitiivi vorm esines tavapäraselt verbidega kuulma ja mõtlema: kuulen sõna kultuur, ma kuulen sõna, kui kuulete sõna ja on mõeldud sõna < <on> mõeldud sõna neljakesi. Veel on kasutatud ainsuse adessiivi (sõnal võib olla) ja mitmuse komitatiivi vorme (<minu> jaoks seostub sõnadega).

\subsection{Kokkuvõtvalt tekstiloomes eelistatud konstruktsioonidest ja käändevormidest}

Kui nimisõnade vormistatistika andis ülevaate kirjakeele ja õppijakeele käändeparadigmade samalaadsusest ning sünkroonsusest, teatud vormide suhtelisest üleja alakasutusest õppijakeeles, siis käändevormide kasutuseelistused kaks ja enam korda ilmnenud konstruktsioonides kitsendavad oluliselt nende käänete hulka, mida eesti keeles tegelikult tarvitatakse. Statistika järgi on EKI tekstikorpuses sõna inimene käändeparadigma kõige sagedasem vorm ainsuse partitiiv. Kirjakeelele iseloomulike konstruktsioonide kasutusmustrites on aga sellele vormile eelistatud ainsuse nominatiivi: inimene ja seadus inimene ja loodus; kui (et) inimene on; inimene ei ole (ei saa). Samalaadne nihe on iseloomulik ka ülejäänud sõnadele. Kirjakeeles on sõna paradigma sagedasemad vormid ainsuse ja mitmuse nominatiiv, mitmuse genitiiv, ainsuse partitiiv ja genitiiv, samas kui kirjakeele tekstiloomes on eelistatud konstruktsioone, milles on võimalikud vaid kolm käänet: 1) ainsuse nominatiiv (tehnika vïmane sõna), 2) ainsuse genitiiv (sõna otseses mõttes (tähenduses), selle sõna otseses, oma viimase sõna, oma sõna öelda); 3) mitmuse genitiiv (tema (oma) sõnade kohaselt (järgi, eest)). Sõna elu puhul on kirjakeeles käändevormide sageduse ja nende kasutuseelistuste erinevus veelgi selgem. Paradigmas on suurem osakaal semantilistel käänetel (ainsuse inessiiv, elatiiv, nominatiiv, genitiiv, allatiiv, terminatiiv), samas kui kirjakeele tekstiloomes on eelistatud kasutada konstruktsioone, kus on võimalik vaid ainsuse nominatiiv (haridus ja elu kultuur ja elu; 
tema ( $t a$ ) elu on). Sõna aeg vormistatistika alusel on kirjakeeles sagedasemad ainsuse partitiiv, nominatiiv, adessiiv ning mitmuse nominatiiv ja genitiiv, samas kui korduvalt kasutatud konstruktsioonides on aga eelistatud vaid kahte käändevormi: 1) ainsuse nominatiiv (<on> teoinimeste aeg $\sim$ käes <on> teoinimeste aeg; on ilus (paras, viimane, õige) aeg; mõni aeg hiljem mõni aeg pärast <mida >; on (oli, olnud, ajanud) kogu aeg; aeg on kallis aeg on möödas (läbi, käes); et viimane aeg oli aeg mil); 2) ainsuse partitiiv (kuu aega tagasi (hiljem, enne); umbes (ligi, ja) kuu aega;juba pikka aega väga pikka aega; oli (on) pikka aega pikka aega on; tükk aega tagasi (pärast) nädal aega tagasi; on veel aega vajan veidi aega). Eespool analüüsitud nelja sagedasema nimisõna käändevormide sageduse ja kasutuseelistuste võrdlusest tuleb selgelt esile, et tegelikult on eesti kirjakeele tekstiloomes eelistatuim vorm ainsuse nominatiiv.

Ka õppijakeele analüüs näitas teatud disproportsiooni vormi sageduse ja kasutuseelistuste vahel kindlat tüüpi konstruktsioonides, kuid need erinevused olid siiski väiksemad kui kirjakeeles. Näiteks sõna inimene puhul on nominatiivi vormisagedus nii paradigmas kui ka tekstiloomes eelistatud konstruktsioonides ühesugune (ainsuse nominatiiv - mitmuse nominatiiv, sageduselt kolmas on mitmuse genitiiv, konstruktsioonides aga ainsuse genitiiv). Eriti rikkalikult on õppijakeeles kasutatud konstruktsioone ja nende leksikaalgrammatilisi variante ainsuse nominatiiviga: $k u i$ inimene on (tahab, kogeb, elab, suhtleb) et inimene peab ja kui (et kui, sest kui) inimene; inimene peab olema (maksma, teadma) inimene võib töötada inimene ei saa (ei ole); haritud (iga) inimene peab (saab, võib, tahab). Mitmuse nominatiiv on esindatud kahes sagedases konstruktsioonis ja nende leksikaalgrammatilistes variantides: kõik (need) inimesed on (hoidsid, tahavad); inimesed kes on (ei ole). Niisugust kokkulangevust ainsuse ja mitmuse nominatiivi sageduse ja tegeliku vormikasutuse vahel võib pidada õppijakeelele omaseks, nominatiivi eelistamist kirjakeele ja õppijakeele tekstiloomes aga samalaadseks tendentsiks. Sõna inimene ülejäänud käändevormide sageduse (mitmuse genitiiv, ainsuse partitiiv, mitmuse partitiiv, ainsuse genitiiv) ja kasutuseelistuste vahel on erinevus kirjakeelest vaid selles, et õppija on rohkem kasutanud ainsuse genitiivi ja partitiivi (ainsuse genitiiv, mitmuse genitiiv, ainsuse partitiiv ja mitmuse partitiiv): 1) ainsuse genitiiv (mõjutab (ei mõjuta) inimese elu inimese elu mõjutab; inimese elu kõige ?inimese elu haridus *inimese elu tema (?teema) *inimese elu ma (?maal)); 2) mitmuse genitiiv (matkida inimeste magamisasendit); 3) ainsuse partitiiv (ainult (umbes) kuus (sada) inimest; ning kaheksa (üksteist) inimest; kaheksa (kuus) inimest 32-st; üksteist inimest kirjutasid); 4) mitmuse partitiiv (väga (nii) palju inimesi).

Ka teiste analüüsitud sõnade puhul on õppijakeeles tegu samalaadsete nähtustega. Näiteks sõna sagedasematest käänetest (mitmuse nominatiiv, komitatiiv ja genitiiv; ainsuse komitatiiv ning nominatiiv) on õppija eelistanud konstruktsioone, milles saab kasutada vaid kolme käänet: 1) ainsuse nominatiiv (sõna eesti kultuur; väga levinud sõna nö esimene sõna; esimene sõna mis); 2) mitmuse genitiiv (hümni sõnade kirjutaja (autor); Eesti hümni sõnade; et hümni sõnade; sõnade autor oli); 3) ainsuse partitiiv (kuulen sõna kultuur; ma kuulen sõna; kui kuulete sõna; on mõeldud sõna <on> mõeldud sõna neljakesi). Sõna elu käändevormide sageduse ja kasutatavuse vahe on analoogne: sagedusreast ainsuse inessiiv, nominatiiv, genitiiv, partitiiv ja elatiiv on tekstiloomes eelistatud vaid kolme vormi 1) ainsuse nominatiiv (inimese elu on (võib, sõltub, erineb); elu sõltub elukohast; $<$ meie > elu erineb Ukraina <elust >; elu on väga); 2) ainsuse genitiiv (ja vanemate 
elu et noorte elu et inimese elu); 3) ainsuse partitiiv (inimese elu mõjutab mõjutavad inimese elu). Sõna aeg vormiparadigmas on õppijakeeles sagedasemad ainsuse adessiiv, partitiiv, nominatiiv ja genitiiv. Ent konstruktsioonides, mida õppija tekstiloomes on selle sõnaga eelistatud, ilmneb kõigepealt mitmuse genitiivi vorm (kõigi aegade suurim (parim, esimene, teine); on läbi aegade läbi aegade on; on kõigi aegade; ESTO-d läbi aegade; Eesti kõigi aegade), järgnevad ainsuse partitiiv (vabadus (vajadus, *vabanduse) planeerida aega; pidis (pidab, pidada, pidama) mõnda aega; väga vähe aega nii palju aega liiga palju aega; ei ole (ei olnud) aega), ainsuse nominatiiv (see aeg on mõni aeg oli; muutub (on) kogu aeg; on aeg kus; lendab aeg väga) ja ainsuse genitiiv (<mõne> aja pärast tuli (oli)). Niisiis on õppijakeele tekstiloomes eelistatud konstruktsioonides kasutusel vaid kindlad käändevormid, mida vormisageduse statistika alusel käändeparadigmas oleks raske olnud eeldada. Õppijakeele vaieldamatult eelistatuim kääne on nominatiiv, samas aga olenevalt sõna semantikast on tarvitatud konstruktsioone, milles saab kasutada vaid semantilisi käändeid. Nende konstruktsioonide korduvus EVKK-s on hüppeliselt kõrge ja silmatorkava leksikaalgrammatilise varieeruvusega, kirjakeeles aga tunduvalt tagasihoidlikum või mitteoluline. Näiteks sõnaga aeg on õppijakeele tekstiloomes eelistatud konstruktsioonides kasutatud põhiliselt ainsuse adessiivi: külmal ajal peab; et (kuid, sest) sel ajal sest tol ajal ja samal ajal; tol (sellel) ajal tekkis (kasutati) samal ajal läksid praegusel (sel, sellel) ajal on vabariigi (vene, ${ }^{*}$ tsari) ajal oli sõja ajal polnud vabal (vabariigi) ajal teha; samal ajal ajaloolised <sündmused $>\sim$ tol ajal inimesed $\sim$ sel ajal laulud. Teiste sõnadega esines ainsuse adessiivi küll harvem, kuid konstruktsioone, kus seda vormi on kasutatud, iseloomustab leksikaalgrammatiline varieeruvus: $k u i$ inimesel on (ei ole); igal inimesel on (peab olema); sõnal võib olla. Sõna elu tarvitati õppijakeeles aktiivselt konstruktsioonides, mis nõudsid ainsuse inessiivi (minu elus on (oli) meie elus on; elus on palju (väga)), ning sõna konstruktsioonides, milles on vaja kasutada mitmuse komitatiivi (<minu > jaoks seostub sõnadega). Seega on õppijakeeles tihti korduvates konstruktsioonides lisaks grammatilistele käänetele esindatud ka semantilised, kuid kirjakeele tekstiloomele pole see omane.

Lahknevused kirjakeele ja õppijakeele käändekasutuse konstruktsioonieelistustes annavad teavet ka võrreldavate keelevariantide diskursuserinevuste kohta ning toovad esile sel otstarbel kasutatud stereotüüpsed konstruktsioonid. EKI tekstikorpuses on esile tõstetud inimese, seaduse ja looduse ning elu, hariduse ja kultuuri küsimusi ühiskonnas. Oluliseks on peetud seda, missuguseid inimesi üldse on. Kirjakeeles on olnud tähtis teada anda, kui palju inimesi on õnnetustes või katastroofides viga saanud / hukkunud. Õppijakeelele seevastu on omane modaalsete hinnangute andmine, arutlused teemal, mida inimene oma elus teha võib ning mida ta teha ei tohi või tegema peab. Rõhutatult positiivselt on esile toodud teatud hulka inimesi, kes midagi teevad. Eelistatakse kirjutada neist, kes midagi on saavutanud (nt vabaduse, iseseisvuse, tulemuse spordis, kultuuri alal, majanduses).

Kirjakeele iseloomulikuks jooneks on mõningate stereotüüpsete konstruktsioonide kasutamine teksti sidususvahendina või hinnangu edastamiseks: on (käes) teoinimeste aeg; sõna otseses mõttes (tähenduses); selle sõna otseses (kõige <otsesemas mõttes, tähenduses >); tema (oma) sõnade kohaselt (järgi); tehnika vïmane sõna oma viimane sõna oma viimase sõna; oma sõna öelda (ütlema). Need kirjakeeles stereotüüpsetena kasutatud konstruktsioonid pole õppijakeelele omased, v.a hinnangu väljendamiseks kasutatud stereotüüp vabadus (vajadus) planeerida aega. 


\section{Lõpetuseks}

Eesti keele kahe kasutusvariandi võrdlemise tulemuste põhjal võib järeldada, et nii loomulikus keelekasutuses kui ka õppijakeeles on grammatiliste käänete puhul suundumus eelistada nominatiivi ja semantiliste käänete puhul inessiivi, adessiivi ning komitatiivi. Edaspidine laiemapõhjaline uuring peaks näitama, kas tegu on üldisema nominatiivistumisega, ning tõlgendama erinevaid asjaolusid, millest see protsess võiks olla tingitud.

Sõna käändevormide statistiline sagedus korpusaineses ei seleta, millised käändekasutusmustreid läheb vaja, et tekste produtseerida ning nendest aru saada. Vormikasutuse mõistmiseks oleks vaja teada, missugustes leksikaalsetes üksustes, konstruktsioonides ja nende variantides grammatilisi vorme reaalselt kasutatakse. Siit saaks teavet ka selle kohta, kuidas sõna semantika ja grammatika süntagmaatilisel tasandil omavahel põimuvad. Samuti oleks mõttekas välja selgitada, milliste lingvistiliste ja ekstralingvistiliste asjaoludega on seotud teatud tüüpi konstruktsioonide korduv kasutamine erinevat liiki tekstide produtseerimisel (teema, eesmärgid, register, tekstitüü, sotsiaalne interaktsioon jms).

Leksikaalsete üksuste, grammatiliste vormide ja konstruktsioonide statistiline väljatoomine võimaldab keeleainest analüüsides leida lingvistilist teavet nähtuste kohta, milleni traditsioonilise korpuspõhise lingvistilise analüüsi tulemusel ei pruugi jõuda, kuid mis tegelikult on keelekasutusele omased. Seetõttu on korpusest tulenevad, erinevat statistikal põhinevat keeletarkvara kasutavad uurimused perspektiivikad ning rakenduslikult (keeleõpe, tõlkimine, sõnastikud, õppematerjalid) olulised.

\section{Viidatud kirjandus}

Atkins, Sue; Clear, Jeremy; Ostler, Nicholas 1992. Corpus design criteria. - Literary and Linguistic Computing, 7 (1), 1-16. doi:10.1093/llc/7.1.1

Baker, Mona 1995. Corpora in translation studies: An overview and suggestions for future research. - Target, 7 (2), 223-243.

Berber-Sardinha, Tony 1999. Using Key Words in text analysis: Practical aspects. http:// www2.lael.pucsp.br/direct/DirectPapers42.pdf (12.10.2008).

Bergh, Gunnar 2005. Min(d)ing English language data on the Web: What can Google tell as? - ICAME Journal. Computers in English Linguistics, 29, 25-46.

Biber, Douglas 1993. Representativeness in corpus design. - Literary and Linguistic Computing, 8 (4), 243-257. doi:10.1093/llc/8.4.243 [2nd ed. in: Practical lexicography: A reader. Ed. by Thierry Fontenelle. Oxford: Oxford University Press, 63-88.]

Chambers, John M. 2007. Software for Data Analysis: Programming with R. New York: Springer.

Eslon, Pille 2008. Käändevormide kasutussageduse võrdlus eesti õppijakeeles ja kirjakeeles. Pille Eslon (toim.). Õppijakeele analüüs: võimalused, probleemid, vajadused. Eesti filoloogia osakonna toimetised 10. Tallinn: Tallinna Ülikooli kirjastus, 31-66.

Granger, Sylviane 1998. Prefabricated patterns in advanced EFL writing: Collocations and formulae. - Anthony Paul Cowie (Ed.). Phraseology: Theory, analysis, and applications. Oxford: Oxford University Press, 145-243.

Granger, Sylviane 1997. On identifying the syntactic and discourse features of participle clauses in academic English: Native and non-native writers compared. - Jan Aarts, Inge de Mönnink, Herman Wekker (Eds.). Studies in English Language and Teaching. Amsterdam: Rodopi, 185-198. 
Hanston, Susan 2002. Pattern grammar, language teaching, and linguistic variation: Applications of a corpus-driven grammar. - Randi Reppen, Susan Fitzmaurice, Douglas Biber (Eds.). Using Corpora to Explore Linguistic Variation. Amsterdam/Philadelphia: John Benjamins, 167-186.

Hoey, Michael; Mahlberg, Michaela; Stubbs, Michael; Teubert, Wolfgang (Eds.) 2007. Text, Discourse, and Corpora: Theory and Analysis. With an Introduction by John Sinclair. London, New York: Continuum International Publishing Group.

Jantunen, Jarmo Harri 2004. Synonymia ja käännössuomi. Korpusnäkökulma samamerkityksisyyden kontekstuaalisuuteen ja käännöskielen leksikaalisiin erityispiirteisiin. Joensuun yliopiston humanistisia julkaisuja 35. Joensuu: Joensuun yliopisto.

Heiki-Jaan Kaalep, Kadri Muischnek. Eesti kirjakeele sagedussõnastik. Tartu: Tartu Ülikooli Kirjastus, 2002.

Kennedy, Graeme 2002. Variation in the distribution of modal verbs in the British National Corpus. - Randi Reppen, Susan Fitzmaurice, Douglas Biber (Eds.). Using Corpora to Explore Linguistic Variation. Amsterdam/Philadelphia: John Benjamins, 73-90.

Kennedy, Graeme 1999. An Introduction to Corpus Linguistics. London, New York: Longman.

Leech, Geoffrey 1981. Semantic. The Study of Meaning. London: Penguin Books.

McEnery, Anthony; Wilson, Andrew 2001. Corpus Linguistics. Edinburgh: Edinburgh University Press.

Meier, Heidi 2003. Essee asend allkeelte tekstitüübivõrdluses. Magistritöö. Käsikiri Tallinna Ülikooli eesti keele ja kultuuri instituudis.

Muischnek, Kadri 2006. Verbi ja noomeni püsiühendid eesti keeles. Dissertationes philologiae Estonicae Universitatis Tartuensis 17. Tartu: Tartu Ülikooli Kirjastus.

Nesselhauf, Nadja 2005. Collocations in a Learner Corpus. Amsterdam, Philadelphia: John Benjamins.

Nesselhauf, Nadja; Römer, Ute 2007. Lexical-grammatical patterns in spoken English: The case of the progressive with future time reference. - International Journal of Corpus Linguistics, 12 (3), 297-333. doi:10.1075/ijcl.12.3.02nes

Orpin, Debbie 2005. Corpus linguistics and critical discourse analysis: Examining the ideology of sleaze. - International Journal of Corpus Linguistics, 10 (1), 37-61. doi:10.1075/ ijcl.10.1.03orp

Römer, Ute 2007. Learner language and the norms in native corpora and EFL teaching materials: A case study of English conditionals. - Sabine Volk-Birke, Julia Lippert (Eds.). Anglistentag 2006 Halle. Proceedings. Trier: Wissenschaftlicher Verlag Trier, $355-363$.

Römer, Ute 2005. Progressives, Patterns, Pedagogy: A Corpus-driven Approach to English Progressive Forms, Functions, Contexts and Didactics. Studies in Corpus Linguistics 18. Amsterdam: John Benjamins.

Scott, Mike; Tribble, Christopher 2006. Textual Patterns: Key Words and Corpus Analysis in Language Education. Philadelphia: John Benjamins.

Sinclair, John 1991. Corpus, Concordance, Collocation. Oxford: Oxford University Press.

Stubbs, Michael 1996. Text and Corpus Analyzis. Oxford: Blackwell Publishing.

Sõrmus, Kadri 2008. Emakeeleõppija korpus. Statistiline analüüs ja veamärgendussüsteem. Magistritöö. http://dspace.utlib.ee/dspace/bitstream/10062/6217/1/sormus_kadri. pdf (9.09.2008).

Tognini Bonelli, Elena 2002. Functionally complete units of meaning across English and Italian: Towards a corpus-driven approach. - Bengt Altenberg, Sylviane Granger (Eds.). Lexis in Contrast. Corpus-based Approaches. Philadelphia: John Benjamins, 73-95.

Volk, Martin 2002. Using the Web as corpus for linguistic research. - Renate Pajusalu, Tiit Hennoste (toim.). Tähendusepüüdja. Tartu Ülikooli üldkeeleteaduse õppetooli toimetised 3. Tartu: Tartu Ülikooli Kirjastus, 355-369. 
Xiao, Zhonghua; McEnery, Anthony 2005. Two approaches to genre analysis: Three genres in Modern American English. - Journal of English Linguistics, 33 (1), 62-82. doi:10.1177/0075424204273957

Pille Eslon (Tallinna Ülikool). Viimase aja teadustegevus on seotud eesti õppija- ja kirjakeele korpusest tuleneva kõrvutava uurimisega. Teadustöö teoreetiline taust on funktsionaalgrammatiline: keelte uurimisel on lähtutud keelendite funktsionaalsest potentsiaalist ja kategooriate koosmõjust erinevates kontekstides. Kitsamad uurimisvaldkonnad on aspektuaalsus, temporaalsus, modaalsus ja grammatisatsioon. pille.eslon@tlu.ee.

Erika Matsak (Tallinna Ülikool). Uurimisvaldkonnad on loogilised konstruktsioonid eestikeelsetes tekstides; vahendite loomine tekstides sisalduvate leksikaalsete mallide ja grammatiliste konstruktsioonide automaatseks eraldamiseks ning grammatiliste reeglite esiletoomiseks; keele kasutusmallide kvantitatiivne analüüs.

matsak@tlu.ee. 


\title{
CORPUS-DRIVEN COMPARATIVE ANALYSIS OF VARIANTS OF ESTONIAN
}

\author{
Pille Eslon, Erika Matsak \\ Tallinn University
}

The objective of the study was to compare the use of case forms in two variants of Estonian - standard language and learner language. The material was taken from the Standard Estonian corpus of the Institute of the Estonian Language and the Estonian interlanguage corpus of Tallinn University. The frequency of the inflectional forms of the four most common nouns in Estonian (inimene 'person', sõna 'word', elu 'life' ja aeg 'time') is found out and their morphological paradigms and synchronicity are described. The statistics showed to what extent semantics tells on the formation and frequency of grammatical forms.

Unfortunately the statistics of case forms gives us only the frequency of forms in a sample (e.g. the most frequent cases of the word aeg 'time' in the Standard Estonian corpus are SG.PART, SG.NOM, SG.ADS, PL.NOM, PL.GEN), but it does not say much about contextual preferences (e.g. in the Standard Estonian corpus the following constructions containing the word aeg 'time' in SG.NOM are preferred: <on> teoinimeste aeg 'it is time for people of action' käes <on> teoinimeste aeg 'the time has come for people of action'; on ilus (paras, viimane, õige) aeg it is a beautiful (a good, high, the right) time'; mõni aeg hiljem 'a little later' mõni aeg pärast <mida> 'a little after <something>'; on (oli, olnud, ajanud) kogu aeg 'all the time it is (was, had been, had made)'; aeg on kallis 'time is valuable' aeg on möödas (läbi, käes) 'the time is over (is up, has come)'; et viimane aeg 'that <it is > high time' oli aeg mil 'there was a time when', and with SG.PART: kuu aega tagasi (hiljem, enne) 'a month ago (later, before); umbes (ligi,ja) kuu aega 'about (around, and) one month'; juba pikka aega 'for a long time already' väga pikka aega 'for a very long time'; oli (on) pikka aega 'was (has been) for a long time' pikka aega on 'has <done something > for a long time'; tükk aega tagasi (pärast) 'a long time ago (after <something>)' nädal aega tagasi 'a week ago'; on veel aega 'there is time yet' vajan veidi aega 'I need a little time').

Analysis of contextual preferences is necessary for pedagogical and lexicographical purposes, and, importantly, also for making explicit the hidden tendencies that are working in the language system synchronically. For this purpose, the grammatical constructions and their lexico-grammatical variants (allowing only certain case forms) typical of Standard Estonian and learner Estonian were found out. This reduced significantly the number of the case forms eligible for further analysis. Mere statistics of case forms would never have provided the data on their use in constructions and on their preference order in text production.

From a comparison of the frequencies of the case forms in learner language versus Standard Estonian it appeared that there is an overwhelming tendency in learner language to use the nominative case above all (inimene 'person' - in singular and plural, sõna 'word' - in plural, elu 'life' - in singular). However, the nominative is a frequent form in Standard Estonian as well (sõna 'word' - in nominative singular and nominative plural holds the first place in the frequency list of 
word forms, inimene 'person' - nominative plural holds the second place in the frequency list after partitive singular; nominative singular holds the third place, aeg 'time' - nominative singular holds the third place after inessive singular and elative singular). There are only two words in the standard language that slightly prefer the partitive (inimene, aeg). This evidence calls into question the statement that in the Estonian case system there is an oppositional pair consisting of the nominative and partitive cases, of which the partitive is the unmarked member.

In case the learner language and standard language lacked synchronicity, then it could be assumed that it is a manifestation of atypical use of word forms, which is worth studying. But the results of this study showed that in both language variants, the clearly preferred case is the nominative. Further research should reveal whether this phenomenon can be considered a process of nominativization, and what its possible motivations could be. The next most preferred semantic cases in both standard and learner language were the inessive, the adessive and the comitative. The frequency of case forms of a word does not explain, though, which patterns of case usage are necessary to actually produce and understand texts.

Statistical representation of lexical units, grammatical forms and constructions has enabled us to reveal such linguistic data that, despite being characteristic of language use, is not easily accessible by traditional corpus-based analysis. Therefore we believe that corpus-driven studies using statistical and language software have a long-term theoretical and applied value (in language teaching, translation, dictionaries and learning materials).

Keywords: corpus linguistics, corpus-driven comparative analysis, inflectional grammar, case preferences in Estonian usage, Estonian language 